\title{
Endüstri 4.0 ve Teknolojinin İstihdam Üzerindeki Etkisi, Panel Veri Analizi ${ }^{2}$
}

\section{Impacts of Industry 4.0 and Technology on Employment, Panel Data Analysis \\ Ela BULUT ${ }^{3}$ a \\ Aslı YENIPAZARLI ${ }^{4}$}

\begin{abstract}
${ }^{3}$ Pamukkale Üniversitesi, Sosyal Bilimler Enst.İktisat ABD elabulut48@gmail.com Orcid ID: 0000-0002-0771-9654 ${ }^{4}$ Aydın Adnan Menderes Üniversitesi Nazilli İ.̇..B.F. İktisat ABD ayenipazarli@adu.edu.tr Orcid ID: 0000-0002-5078-3037 aYazış1lan yazar/Corresponding author
\end{abstract}

$\begin{array}{ll}\text { Makale Bilgisi: } & \text { Araştırma Makalesi } \\ \text { Geliş Tarihi: } & 19.04 .2020 \\ \text { DüzeltmeTarihi: } & 04.09 .2020 \\ \text { Kabul Tarihi: } & 02.11 .2020\end{array}$

\section{Özet}

Endüstri 4.0 yeni bir dijital çă̆ın başlangıcı olarak, teknolojinin her alanda aktif kullanımın katkıda bulunmaktadır. 3D yazıcılar, çıkartmalı üretim sistemlerinin yerini eklemeli üretim sistemlerinin almasina neden olarak üretimdeki çıktı artığını ortadan kaldırmaktadır. "Nesnelerin Interneti" makineden makineye (M2M) bilgi aktarımın sağlarken, "Akıllı Fabrikalar" üretimdeki emek gücünü minimum seviyeye indirmektedir. Bununla birlikte teknolojinin istihdam üzerindeki etkisi tekrar tartışılmaya başlanmış ve bu konuda farklı görüşler ortaya çıkmıştır. Bu çalışmanın amacı teknolojinin istihdam üzerinde oluşabilecek etkilerini anlamaya çalışmaktır. Teknoloji göstergeleri olarak ArEGe harcamaları ve yüksek teknoloji ihracatı verileri kullanılmıştır. Gelişmiş, gelişmekte olan ve az gelişmiş 81 ülke verileri dengesiz panel veri analizi genelleştirilmiş en küçük kareler yöntemi (GEKK) ile tahmin edilmiştir. ArEGe harcamaları ve yüksek teknoloji ihracatını istihdam üzerindeki etkilerinin farklllık göstermektedir. Çalışmada üretim süreçlerinde gerçekleşen teknolojik gelişimlerin istihdamı azalttı̆̆̆, yeni ürün üretimi ile sonuçlanan teknolojik gelişimlerin ise istihdamı arttırıcı etkisi olduğu gözlenmiştir. Üretim süreçlerinde ortaya çıkan teknolojik gelişmelerin istihdamı olumsuz etkilediğ $i$ tespit edilmiştir.

Anahtar Kelimeler: İstihdam, ArEGe, Endüstri 4.0

JEL kodlart: A10, C33, O30

\author{
Article Info: \\ Date Accepted: $\quad 02.11 .2020$
}

\begin{abstract}
Industry 4.0 contributes to the active use of technology in all areas as the beginning of a new digital age. $3 D$ printers eliminate the surplus of output in production by causing additive manufacturing systems to replace subtractive production systems. While the "Internet of Things" enables the transfer of information from machine to machine (M2M), "Smart Factories" reduce the labor force in production to a minimum. However, the effect of technology on employment has started to be discussed again and different opinions have emerged on this issue. The aim of this study is to try to understand the effects of technology on employment. RED expenditures and high technology export data are used as technology indicators. Data from developed, developing and underdeveloped 81 countries are estimated by using unbalanced panel data analysis generalized least squares method (GEKK). The effects of RED expenditures and high technology exports on employment differ. It was observed in the study that technological developments in production processes reduce employment, while technological developments resulting in new product production have an employment-increasing effect. It has been determined that technological developments in production processes have a negative impact on employment.
\end{abstract}

Keywords: Employment, RED, Industry 4.0

JEL codes: A10, C33, O30

\footnotetext{
1 “Endüstri 4.0'ın gelişimi, Türkiye ve dünya üzerindeki olası etkileri” isimli yüksek lisans tezinden yararlanılarak hazırlanmıştır. ${ }^{2}$ Çalışma etik kurul ve yasal izin alınması kapsamında değildir. İntihal raporu alınmıştır.
} 


\section{GİRIŞ}

Endüstri 4.0 kavramı ilk olarak Almanya'nın Hannover kentinde 2011 yılında ortaya çıkmıştır. Bu kavram ortaya çıktıktan sonra birçok gelişmiş ülke Endüstri 4.0 için komisyonlar kurmuş ve inovasyon çalışmalarına hız kazandırmıştır. Ülkeler dördüncü sanayi devrimi yarışında öne çıkabilmek için tüm kuruluşlarını ve sanayi sektöründeki firmaları seferber etmiştir. Öte yandan Endüstri 4.0 yeni bir devrim mi yoksa üçüncü sanayi devriminin devamı mı tartışmaları devam etmektedir. Fakat dördüncü sanayi devriminin en büyük tartışması işsizlikte ortaya çıkması beklenen artıştır. Bu konuda birçok farklı görüş bulunmaktadır. İyimser görüş işsizliğin ortaya çıkacak yeni işlerle telafi edilebileceğini iddia ederken, kötümser görüş ise işsizlikte ortaya çıkacak artışın yeni işlerle telafi edilemeyecek kadar büyük bir boyutta olacağını savunmaktadır. Bu tartışma endüstri 4.0 ile ortaya çıan teknolojik gelişmelerin işsizlik üzerindeki etkisini anlamaya çalışmanın önemli olduğunu göstermektedir.

Çalışmanın amacı teknoloji göstergeleri ile istihdamın bugüne kadar nasıl etkilendiğini dengesiz panel veri yöntemi ile anlamaya çalışmaktır. Buradaki temel hedef teknolojinin istihdam üzerindeki olumlu ya da olumsuz etkisini ortaya çıkarmaktır. Bu nedenle gelişmiş, gelişmekte olan ve az gelişmiş ülkelerin istihdam ve teknoloji verileri, veri eksikliği nedeniyle dengesiz panel kurularak gözlenmeye çalışılmıştır. 1998-2017 dönem aralığında 81 ülkenin istihdam göstergeleri ile Ar\&Ge ve yüksek teknoloji ihracatı arasındaki ilişki dengesiz panel veri analizi yöntemi ile tahmin edilmiştir. Çalışma sonucunda üretimde gerçekleşen inovatif süreç ile üründe gerçekleşen inovatif süreçlerin istihdam üzerinde farklı etkilerinin olduğu görülmüştür.

\section{TEKNOLOJI GÖSTERGESI OLARAK AR\&GE HARCAMALARININ EKONOMIDEKI ETKILERI}

Ar\&Ge sayesinde firmalar önemli bulgular elde ederek ürünlerini daha verimli ve piyasadaki talebe uygun olarak üretebilmektedir. Aynı zamanda görsel açıdan müşterilerinin dikkatlerini çekecek şekilde tasarımlar yaparak piyasada rekabet koşullarına uyum sağlayabilmektedir. Ar\&Ge harcamaları hem üretilen ürünlerin yeniden tasarlanması ve üretim süreçlerinin geliştirilmesi hem de yeni ürünlerin üretilmesi için kullanılmakta olduğundan dolayı teknoloji girdisi yerine kullanılabilen temel bir veri özelliğine sahiptir. Bu sebepten sanayi devrimlerini incelemek aynı zamanda Ar\&Ge harcamalarının yönünü takip etmek anlamına gelmektedir. Ar\&Ge harcamaları, teknoloji açısından temel veri kabul edilmekte ve panel veri analizi yöntemi ile kurulan regresyon modellerinde Ar\&Ge harcamaları ile birlikte ayrica yüksek teknoloji ürün ihracatı verileri teknoloji göstergesi olarak kullanılmaktadır.

\section{1. İktisat Literatüründe Ar\&Ge Harcamaları ve Teknolojik Gelişmenin Ekonomi Üzerine Etkileri}

Araştırma ve geliştirme harcamaları ülkelerin teknoloji geliştirme ve üretme çalışmaları ile ilgili önemli bir değişkendir. Teknolojinin gelişmesi, ülkelerin birçok ekonomik göstergelerinde doğrudan etkiye sahiptir. Büyüme teorilerinde teknoloji, büyümenin içsel bir değişkeni olarak kabul edilmektedir. Solow 1956'da yapmış olduğu çalışmada ülkelerin gelişmişlik düzeylerindeki farkın kapanmayacağını tespit etmiştir. Bu çalışma teknolojinin dışsal olduğu konusunun sorgulanmasına sebep olmuş ve 1957 yılında yapmış olduğu çalışmada N. Kaldor teknik değişimler sayesinde uyarılan verimlilik büyümesi, artan emek - 
sermaye oranının birbirinden ayrı bir şekilde ele alınamayacağını, sermaye - emek oranındaki artışın teknik gelişmenin bir aracı olduğunu ifade etmektedir (Kaynak, 2015: 235). Kendrick 1956'da 80 imalat sanayisi ve 33 sanayi sektörü ile 1899-1953 yılları arasındaki çıtı verilerini kullanarak yapmış olduğu çalışmasında teknolojinin ekonomik büyüme ile ilişkili olduğu ve aynı zamanda teknik ilerlemenin büyümede büyük bir etkiye sahip olduğu sonucuna ulaşmıştır. Romer (1986) ve Lucas (1988) yayınlarında ise teknolojinin içsel bir olgu olduğunu ülkelerin büyüme farklarının sebebinin de teknolojik değişmeler olduğunu ifade etmişlerdir (Özer \& Çiftçi, 2009: 1). Ayrıca G. Schmoller 'da teknolojinin büyümenin bir içsel olgusu olduğunu destekleyen ifadeler kullanmıştır. Schmoller (1923) ekonomi - politik organizasyonun teknolojinin etkisinde kaldığını, teknolojinin iki önemli kökeni bulunduğunu, ekonomi - politik köken ve ruhi - manevi köken olduğunu ifade etmektedir. Bu kökenler birbiri ile karşılıklı etkileşim halinde olmalarına karşın hiçbirinin bir diğerine üstünlüğü olmadığını savunmuştur (Schmoller (1923)'den akt. Derya, 2015: 212). Bir diğer Alman iktisatçı olan Schumpeter (1947) ise teknolojinin getirdiği yaratıcı yıkımın ekonomik gelişmenin önemli bir fonksiyonu olduğunu ifade etmiştir. Shumpeter'e göre teknoloji monopol piyasayı geliştirirken Ar\&Ge harcamaları için fon bulabilen monopol piyasa üretim süreçlerini geliştirecek yeni yöntemleri de ortaya çıkarabilmektedir. Bu sebepten monopol piyasayı engellemek aynı zamanda yaratıcı yıkıma engel olunarak toplumsal gelişme dinamiğine yanlış müdahale gerçekleştirilmiş olacaktır. Yaratıcı yıkımın yanında yenilik teorisini de geliştirmiş olan Shumpeter üretime doğrudan katkı sağlamayan teknolojik değişimi de yenilik olarak kabul etmemiştir (Schumpeter (1947)'den akt. Küçükalay, 2015: 472). D. Acemoğlu \& J. A. Robinson (2013) çalışmasında yaratıcı yıkım gerçekleştiremeyen ve geleneksel kurumları baskı altına alarak sömürdüğü toplumların gelişemeyerek nasıl yıkıldıklarını tarihsel süreç bağlamında ele almışlardır.

\begin{tabular}{|c|c|c|c|c|c|c|c|c|c|}
\hline $\begin{array}{c}\text { Ar\&Ge } \\
\text { Harcamalar1 }\end{array}$ & $\Rightarrow$ & $\begin{array}{c}\text { Yüksek } \\
\text { Teknolojili } \\
\text { Ürün İthalat1 }\end{array}$ & $\Rightarrow$ & $\begin{array}{c}\text { Yüksek } \\
\text { Teknoloji } \\
\text { Ürün Üretimi }\end{array}$ & $\vec{c}$ & $\begin{array}{c}\text { Yüksek } \\
\text { Teknoloji } \\
\text { Ürün İhracat1 }\end{array}$ & $\begin{array}{c}\text { GSYİH } \\
\text { Artı̧̧1 }\end{array}$ & $\Rightarrow$ & $\begin{array}{c}\text { İstihdam } \\
\text { Artış1 }\end{array}$ \\
\hline
\end{tabular}

Şekil 1: Ar\&Ge Harcamalarının Ekonomiye Etkisi Şeması

Ar\&Ge harcamalarının ekonomiye etkisi Şekil 1.'de gösterildiği gibi işlemektedir. Ar\&Ge harcamaları yeni ürünlerin ortaya çıkışını ve diğer ülkelerden yüksek teknolojili ürünlerin ithalatını sağladığı gibi var olan ürünlerin güncellenmesinde ve piyasaya sürülmesinde etkilidir. Yeni yüksek teknoloji içeren ürünler dış talebe bağlı olarak ihracatı arttırmaktadır. İhracatın artışı ülkeye döviz girişini artırarak iktisadi büyümeyi sağlarken aynı zamanda ülkede istihdamın yükselmesine neden olur. Ülkedeki gelir artışı, inovatif ürünlerin piyasada yeni yatırımlarla desteklenerek farklı iş alanlarının açılmasına sebep olacaktır. Teknoloji için kabul edilen genel yargı, ekonomide büyümeyi sağlayacağı, istihdamı arttıracağı ve refah düzeyini yükselteceğidir.

Teknoloji ile işsizlik ilişkisi sanayi devrimleri yaygınlaştığ 1 dönemden itibaren iktisat düşünürleri arasında tartışmalara sebep olmuştur. Teknolojinin ekonomiye katkısı konusunda birçok iktisat teorileri olumlu etki öngörürken istihdama katkısı için çeşitli teoriler geliştirilmiştir.

Teknolojinin istihdama etkisini araştıran iktisatçlardan biri olan M. Vivarelli (2013) çalışmasında firmaların yapmış olduğu Ar\&Ge süreçlerini Şekil 2'deki gibi şemalaştırarak 
teknolojinin gelişmesinin 3 farklı sonucu olduğunu belirtmiştir. Teknolojik yenilik olarak girdi verisi Ar\&Ge harcamaları ve Somut teknolojik değişim (yeni üretim sürecinin ortaya çıkmasını sağlayacak teknik değişim) olarak belirtmiş̧tir. İnovasyon girişi sonucunda ortaya yeni teknolojik ürünler ve yeni teknoloji üretim sistemleri ortaya çıkarken her ikisinin de aynı anda ortaya çıktığı durum da mevcuttur. Bu durumda Vivarelli (2013) şemasına göre yeni ürünün ortaya çıkışını sağlayan teknolojik gelişme, yeni ürün üretimi ile ilgili hem hammadde temini sağlayacak alt firmaların oluşmasına, hem de ürünün satış, pazarlama ve reklam ihtiyacının karşılanması için ilave istihdam artışına sebep olacaktır. Diğer taraftan somut teknolojik değişimin etkisi ile üretim sürecinde ortaya çıkacak yenilikler doğrudan emek tasarrufu sağlayarak istihdam alanlarının daralmasına neden olacaktır. Ürün geliştirmenin emek yoğun etkisi özellikle klasik iktisatçlar tarafından vurgulanmıştır (Say, 1803: 48 Akt. Vivarelli, 2013: 69). Hatta optimist bakış açısının en ciddi eleştirilerinde dahi bu tür yeniliklerin sebep olabileceği pozitif istihdam etkisi kabul edilmiştir (Marx, 1867'den Akt. Vivarelli, 2013: 69).

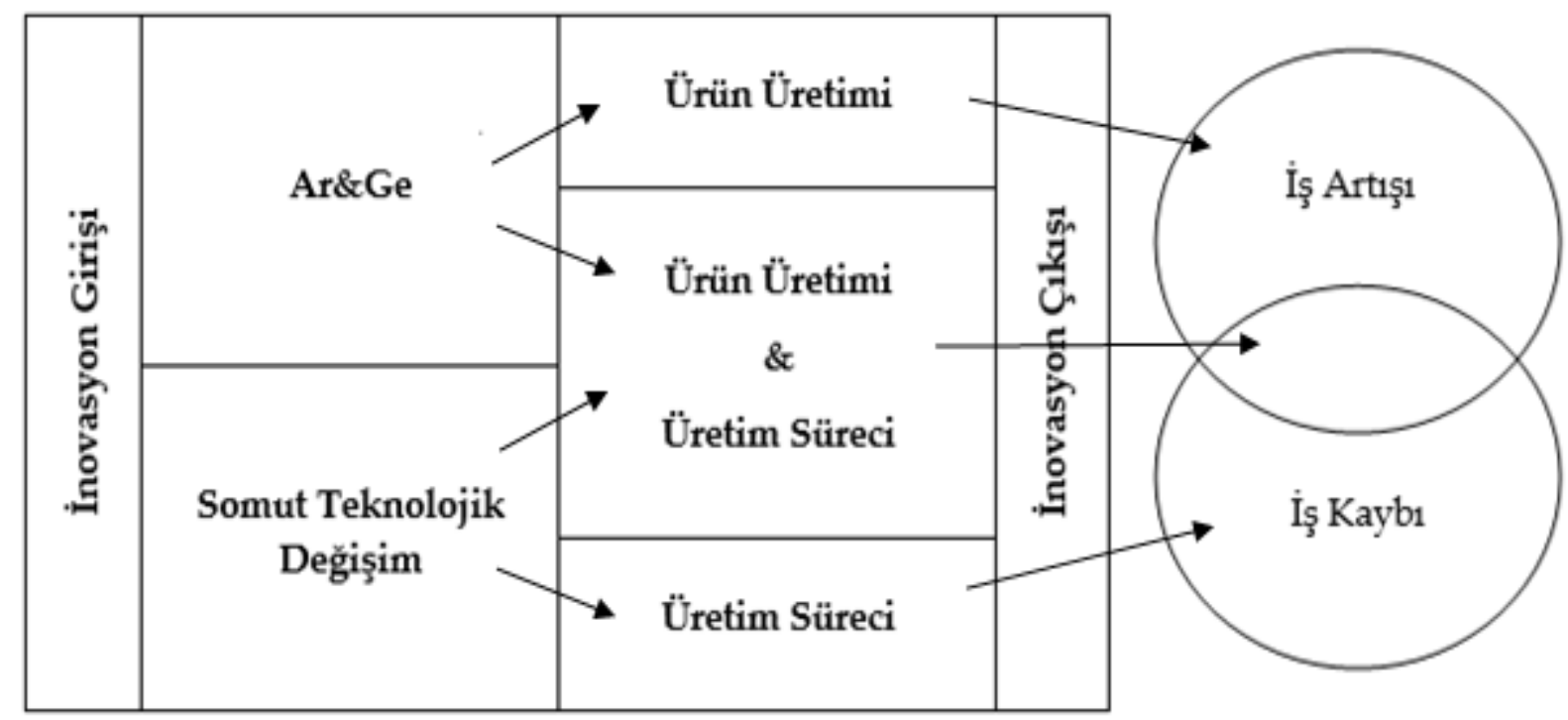

Şekil 2: İnovasyon Gelişim Süreci

Kaynak: Vivarelli, 2013: 69

Ar\&Ge harcamaları, teknolojik ilerleme üzerine kullanılabilecek başka bir veri bulunmasının güçlüğünden dolayı hipotezleri test etmeyi sağladığı için bu çalışmalarda temel bir alan oluşturmuştur (Özer \& Çiftçi, 2009: 1).

\section{DENGESIZ PANEL VERİ ANALİZi}

Panel veri analizi Dengeli ve Dengesiz Panel veri analizi olarak iki şekilde gerçekleştirilebilir. Panel veri analizi yatay kesit ve zaman serilerinin bir havuzda birleştirilmesi ile yapılan regresyon analizlerini ifade etmektedir. Yatay kesitler belli bir zamana ait olan birimlerin yatay serilerini gösterir. Örneğin birden fazla bankanın bir yılda verdiği kredi miktarı, ülkelerin bir yıl içinde gerçekleşen ihracat - ithalat rakamları gibi değişkenlerine ait verilerini içerir. Zaman serisi ise bir birimin belli bir zaman periyodunda ortaya çıkan değişimlerini içermektedir. Örneğin bir ülkenin 10 yıllık ihracat - ithalat rakamları, bir bankanın yıllar içinde vermiş olduğu kredi miktarları zaman serilerini ifade etmektedir (Güriş, 2018: 3). Panel veri 
analizinin ise diğer iki yöntemden farkı hem yatay hem de dikey kesitlerin bir arada bulunarak havuzlama yöntemi ile birlikte hesaplana bilmesidir (Kutlar, 2017: 11). Ayrıca panel veri, belli bir sayıdaki gözlemin, bir zaman aralığındaki gözlemleri ile bir araya getirilerek hesaplanması olarak tanımlanmaktadır. Örneğin 25 OECD ülkesinin işsizlik oranları, milli gelir seviyesi, istihdam oranları gibi yatay gözlemlerin 1990 - 2005 zaman aralığındaki hareketleri panel veriyi oluşturmaktadır (Tatoğlu, 2018: 2).

Bir panel data regresyon modeli;

$$
Y_{i t}=\alpha+X_{i t}^{\prime} \beta+u_{i t}
$$

denklemi ile ifade edilir. Bu denklemde $\mathrm{i}=1,2, \ldots . \mathrm{N}$ tane gözlem sayısını (yatay kesit) ve $\mathrm{t}=$ $1,2, \ldots \mathrm{T}$ kadar zamanı (zaman serisi) ifade etmektedir. $\alpha$ sabit terimi, $\beta$ ise $\mathrm{K}^{*} 1$ matrisi ve Xit ise it gözleminin $\mathrm{K}$ açıllayıcı değişkeni üzerine gözlem değerini ifade etmektedir (Baltagi, 2008: 1; Asteriou \& Hall, 2007: 353). Panel data analizlerinde N gözlem sayısını (ülkeler, kişiler gibi birimleri) $\mathrm{T}$ ise zamanı ifade etmektedir. Panel data analizleri makro panel ve mikro panel olarak ikiye ayrılmaktadır. Makro panel verilerde küçük miktarda N gözlem ile büyük miktarda $\mathrm{T}$ zaman periyodu bulunurken $\mathrm{N}<\mathrm{T}$, mikro panel verilerde ise büyük miktarda $\mathrm{N}$ gözlem olmasına rağmen kısa bir T zaman periyoduna N>T sahiptir (Baltagi, 2008: 1).

\subsection{Ampirik Literatür}

Literatürü incelediğimizde Ar\&Ge harcamalarının panel veri analizlerinde teknolojinin temel değişkeni olarak kullanıldığı birçok çalışmanın mevcut olduğu görülmektedir.

\begin{tabular}{|c|c|c|}
\hline $\begin{array}{l}\text { Çalışmanın } \\
\text { Yazarı ve Yılı }\end{array}$ & $\begin{array}{l}\text { Örneklem ve } \\
\text { Değişkenler }\end{array}$ & Yöntem ve Sonuç \\
\hline $\begin{array}{c}\text { Ebersberger, B. } \\
\text { (2004). }\end{array}$ & $\begin{array}{c}1994 \text { yilı ve } \\
\text { sonrasındaki } 1894 \\
\text { şirketin anket verileri }\end{array}$ & $\begin{array}{l}\text { Devlet tarafından Ar\&Ge harcamaları açısından sübvansiyon } \\
\text { desteği almış } 2750 \text { projeye sahip şirketler ile sübvansiyon almamış } \\
\text { şirketlerin anket verileri karşılaştırılmıştır. Çalışma sonucunda } \\
\text { kamu sübvansiyonlarının şirketlerin yenilikçi çıtılar elde } \\
\text { etmesinde olumlu etkisi olduğunu ayrıca, finansman ile şirketlerin } \\
\text { sonraki işgücü talebi arasında ampirik bir bağlantı bulunduğunu } \\
\text { ve inovasyon için kamu sübvansiyonlarının, şirketlerin istihdam } \\
\text { artışını olumlu yönde etkilediği tespit edilmiştir. }\end{array}$ \\
\hline $\begin{array}{l}\text { Lachenmaier, } \\
\quad \text { S., E } \\
\text { Rottmann, H. } \\
\quad \text { (2011). }\end{array}$ & $\begin{array}{l}\text { Almanya firmaları ile } \\
\text { 1982-2002 yıllarında } \\
\text { yapılan anket verileri }\end{array}$ & $\begin{array}{l}\text { Dinamik panel GMM sistem tahmini kullanılarak ürün yeniliğinin } \\
\text { istihdam üzerinde pozitif etkisi bulunmuştur. Bu aynı zamanda } \\
\text { yenilik girdisi ve çıtısı için geçerlidir. Yeniliklerin istihdam } \\
\text { üzerindeki etkisi bir gecikmeli tahmin edilmiştir. Süreç yenilikleri } \\
\text { ürün yeniliklerine göre daha yüksek etkiye sahip bulunmuştur. }\end{array}$ \\
\hline $\begin{array}{l}\text { Crespi, G., } \mathcal{E} \\
\text { Zuniga, } P . \\
\text { (2012). }\end{array}$ & $\begin{array}{l}\text { Latin Amerika } \\
\text { ülkeleri, inovatif } \\
\text { firmalara yapılmış } \\
\text { anket mikro data } \\
\quad \text { verileri }\end{array}$ & $\begin{array}{l}\text { Latin Amerika ülkelerini içeren mikro veriler ile inovasyon ve } \\
\text { verimlilik arasında ilişki kurulmuştur. Bilgi yatırımı, inovasyon } \\
\text { çıtıları ve firmalar tarafından verimlilik arasındaki ilişkileri } \\
\text { tanımlanmış ve CDM yöntemi ile tahmin edilmiştir. İnovasyonun } \\
\text { verimliliği arttırıcı olumlu etkileri tespit edilmiştir ve ihracatta } \\
\text { yeniliğin firmaların finansmana ulaşımı ile ilişkili olduğu tespit } \\
\text { edilmiştir. }\end{array}$ \\
\hline
\end{tabular}


Tablo 1'in devamı;

\begin{tabular}{|c|c|c|}
\hline $\begin{array}{l}\text { Bogliacino, } F ., \\
\text { Piva, M., E } \\
\text { Vivarelli, } M . \\
\text { (2012) }\end{array}$ & $\begin{array}{l}\text { 1990-2008 yılları } \\
\text { arasında } 677 \text { avrupa } \\
\text { şirketi, iş gücü, } \\
\text { satışlar, ücretler, } \\
\text { Ar\&Ge harcamaları, } \\
\text { yatırım verileri }\end{array}$ & $\begin{array}{l}19 \text { yıllık dönemde Avrupa'daki } 677 \text { şirketin verileri kullanılarak } \\
\text { GMM yöntemi panel veri analizi ile regresyon analizi yapılmıştır. } \\
\text { Yapılan incelemede Ar\&Ge harcamalarının istihdam üzerinde } \% 2,3 \\
\text { oranında çok büyük olmayan bir etkisinin olduğu sonucuna } \\
\text { ulaşılmıştır. Sektörel olarak yapılan incelemede Ar\&Ge } \\
\text { harcamalarının istihdam üzerindeki arttırıcı etkisinin ürün } \\
\text { inovasyonu yapılan sektörlerde (hizmet ve yüksek teknoloji } \\
\text { ürünleri üretimi) gerçekleştiği vurgulanmıştır. }\end{array}$ \\
\hline $\begin{array}{l}\text { Feldmann, } H . \\
\text { (2013). }\end{array}$ & $\begin{array}{l}21 \text { endüstri ülkesi, } \\
\text { 1985-2009 Ar\&Ge } \\
\text { harcamaları, Patent } \\
\text { sayıları, işsizlik } \\
\text { verileri }\end{array}$ & $\begin{array}{l}\text { Ar\&Ge harcamaları ve Patent sayıları temel alınarak yapılan } \\
\text { regresyon analizinde inovasyonların işsizlik üzerine etkisi dinamik } \\
\text { panel GMM yöntemi ile incelenmiştir. Regresyon analizleri hızlı } \\
\text { teknolojik değişimin işsizliği arttırdığını fakat } 3 \text { yıl sonra olumsuz } \\
\text { etkinin kaybolduğunu göstermiştir. Çalışmada teknolojik } \\
\text { değişimin olumsuz etkisinin geçici olduğu sonucuna ulaşılmıştır. }\end{array}$ \\
\hline $\begin{array}{l}\text { Vivarelli, } M . \\
\text { (2013) }\end{array}$ & Teorik inceleme & $\begin{array}{l}\text { Ürün inovasyonu ve üretim süreci inovasyonunun birbiriyle ilişkili } \\
\text { olduğunu ve ürün inovasyonlarının teşvik edilmesi gerektiği } \\
\text { vurgulanmıştır. Süreç inovasyonları sebebiyle ortaya çıacak iş } \\
\text { gücünün yeniden ekonomi içerisine otomatik olarak tazmininin } \\
\text { sağlanması için politikalar üretilmesi gerektiği üzerinde } \\
\text { durulmuştur. }\end{array}$ \\
\hline $\begin{array}{l}\text { Harrison, R., } \\
\text { Jaumandreu, J., } \\
\text { Mairesse, J., E } \\
\text { Peters, B. } \\
\text { (2014). }\end{array}$ & $\begin{array}{l}1998 \text { - } 2000 \text { yılları } \\
\text { Fransa, Almanya, } \\
\quad \text { Ingiltere ve } \\
\text { İspanya'daki } 20.000 \\
\text { seçilmiş firmanın } \\
\text { anket verileri }\end{array}$ & $\begin{array}{l}\text { Yapılmış olan ampirik çalışmada firmaların yenilikçi faaliyetlerinin } \\
\text { istihdam üzerine etkisi analiz edilmiştir. Yenilik hareketleri sonucu } \\
\text { ortaya çıkan istihdam azalışının yeni ürünlerin ortaya çıkardığı } \\
\text { istihdam artışının 3'te birinden daha az olduğu tespit edilmiştir. } \\
\text { Yenilikçi yatırımların istihdam ve iktisadi büyüme açısından } \\
\text { önemli etkisi bulunduğu belirtilmiştir. }\end{array}$ \\
\hline $\begin{array}{l}\text { Dachs, B., } \mathcal{E} \\
\text { Peters, B. } \\
\text { (2014). }\end{array}$ & $\begin{array}{l}16 \text { AB ülkesi, 2002- } \\
2004 \text { yılları inovasyon } \\
\text { anket verileri }\end{array}$ & $\begin{array}{l}\text { Ürün ve üretim süreci inovasyonu olarak iki aşamalı ampirik analiz } \\
\text { sonuçları incelenmiştir. Yabancı firmaların verimlilik artışı } \\
\text { nedeniyle yerli firmalara göre üretim süreci inovasyonu sonucunda } \\
\text { daha fazla istihdam kaybına uğradıkları tespit edilmiştir. Yerli } \\
\text { firmaların istihdam artışının yabancı firmalara göre daha fazla } \\
\text { gerçekleştiği ifade edilmiştir. }\end{array}$ \\
\hline $\begin{array}{c}\text { Bogliacino, } F . \\
\text { (2014). }\end{array}$ & $\begin{array}{l}\text { 2000-2008 yıllarında } \\
\text { firmaların Ar\&Ge } \\
\text { harcamaları. } \\
\text { İstihdam, sermaye } \\
\text { yatırımları verileri }\end{array}$ & $\begin{array}{l}\text { 2000-2008 yılları arasında } A B \text { ve } A B \text { dışı firmaların verileri ile } \\
\text { yapılan Dengesiz Panel analizi sonuçları ile istihdam ve yenilikçi } \\
\text { yaklaşımların etkileri incelenmiştir. Firmaların pazar payındaki } \\
\text { artışında Ar\&Ge'nin istihdam esnekliğini arttıracağı belirtilmiştir. } \\
\text { Hızlı bir yenilikçi üretimin gerçekleştiği sektörde verimliliği } \\
\text { arttırırken istihdamda daha az yetenek gerektiren işlere doğru } \\
\text { değişim gerçekleşmesine sebep olabilir. İnovasyonun istihdam ve } \\
\text { kaynakların yeniden dağılımına neden olduğu, refah düzeyini } \\
\text { dengeleyici politikaların uygulanması gerektiği sonucuna } \\
\text { ulaşılmıştır. }\end{array}$ \\
\hline
\end{tabular}


Tablo 1'in devamı;

\begin{tabular}{|c|c|c|}
\hline $\begin{array}{l}\text { Vivarelli, } M . \\
\text { (2015) }\end{array}$ & Literatür taraması & $\begin{array}{l}\text { Hem teorik hem de ampirik olan literatür, imalat işlerinin kaybında } \\
\text { ve büyük bir işsizlik ortaya çımasında rol oynayabilecek temel } \\
\text { teknolojik itici güçler dikkate alınarak incelenmiştir. Teknoloji } \\
\text { ürünlerinin gelişimi ve üretim süreci geliştirme çalışmalarının } \\
\text { istihdamı etkilediği görülmüştür. Ürün inovasyonu ile sonuçlanan } \\
\text { teknik dönüşüm emek dostu iken süreç inovasyonunun iş } \\
\text { yıkımlarına sebep olduğu gözlenmiştir. Gerçekten de, teknolojinin } \\
\text { istihdam üzerindeki etkisine ilişkin teorik literatürün çoğu, süreç } \\
\text { yenilikçiliğinin teknolojik işsizlik etkilerinin tümü olmasa da en } \\
\text { fazla telafi edebilecek çeşitli piyasa tanzim mekanizmalarına } \\
\text { odaklanmıştır. }\end{array}$ \\
\hline
\end{tabular}

\begin{tabular}{c|c}
\hline Dam, M.M. & 28 OECD ülkesi 1991- \\
(2016) & 2014 yillarına ait \\
& istihdam ve Ar\&Ge \\
harcama verileri
\end{tabular}

\begin{tabular}{c|c}
\hline & \\
\hline Krousie, C. & ABD 2002-2013 \\
(2018) & yıllarına ait işsizlik ve \\
& Ar\&Ge harcamaları \\
verileri
\end{tabular}

$27 \mathrm{AB}$ ülkesi ve 63.561 Firma 2002-

Van Roy, V. E 2013 yillarına ait vd. (2018) Patent sayıları ve temel ekonomik göstergeler 2011 yıllarına ait

Piva, M., E Ar\&Ge harcamaları, Vivarelli, $M . \quad$ istihdam, kişi başı (2018) işgücü tazmini ve sabit sermaye oluşumu verileri
11 AB ülkesi 1998-

Ar\&Ge harcamaları ile Patent sayılarının işsizlik üzerine etkisi Panel veri analizi kullanılarak test edilmiştir ve Ar\&Ge harcamalarındaki \%1'lik bir artışın işsizlik oranında \%10 ve patent sayılarındaki \%1'lik bir artışın ise işsizlikte \%3 oranında bir azalmaya sebep olduğu tespit edilmiştir.

Ar\&Ge harcamaları ile işsizlik arasındaki ilişki 2002-2013 dönemine ait veriler kullanılarak iki aşamalı EKK yöntemi regreyon analizi yapılmıştır. Teknolojik değişim ve işsizlik arasında pozitif bir ilişki tespit edilmiştir. Teknolojinin verimliliğinin işgücü verimliliğinden daha yüksek olduğunu ve bu nedenle teknolojinin doğrudan emeğin yerine geçeceğini tespit etmiştir. Yapay zekanın gelişmesi ile teknolojinin işgücü yerini alacağını ve bunun için hazırlanılması gerektiği belirtilmiştir.

2002-2013 yıllarına ait mikro veriler GMM yöntemi kullanılarak analiz edilmiştir. Yapılan çalışmada patent ağırlıklarının istihdam oluşturmada pozitif katkısının olduğunu tespit etmişlerdir. Olumlu yöndeki istihdam artışının yüksek ve orta teknolojili imalat sanayide olduğu ifade edilmiştir.

1998-2011 dönemi verileri GMM yöntemi ile tahmin edilmiştir. Teknolojinin istihdam üzerindeki etkisinin ürün inovasyonu ve süreç inovasyonu açısından etkisine dikkat çekilmiştir. Ürün inovasyonu ile istihdam arttırıcı süreç inovasyonunda ise istihdamı azaltıcı etkiler olduğu ve bunun işgücü içerisinde tazmin edilebildiğine dikkat çekilmiştir. Yapısal ani bir kriz yaşandığında tazmin mekanizmasının işlemeyebileceği belirtilmiştir. Ayrıca sermaye oluşumunun istihdam üzerinde negatif etkilediği ve bu etkinin teknolojik değişimdeki işgücü tasarrufundan kaynaklanabileceği belirtilmiştir.

42 Ülke 2003-2017

Karabulut, K., Özdemir, D., E Shahinpour, A. (2019) dönemine ait BİT, işsizlik, kişi başına GSYİH ve iş gücü başına sabit sermaye oluşumu verileri
2003-2017 yıllarına ait 21 gelişmiş 21 gelişmekte olan ülkenin işsizlik ile bilişim ve iletişim teknolojisine yapılan harcama verileri panel veri yöntemiyle analiz edilmiştir. Driscroll-Kraay yöntemiyle yapılan analiz sonucunda gelişmekte olan ve gelişmiş ülkelerde işsizlik ve bilgi iletişim teknolojileri harcamaları arasında pozitif yönlü bir ilişki tespit edilmiştir.

Literatür çalışmalarının bazıları dengesiz panel çalışması içerse de çoğunluğunda dengeli panel çalışmaları ile analizler gerçekleştirilmiştir. Bu analizler veri kısıtı sebebiyle genellikle gelişmiş ülkelerdeki işsizlik oranları ile Ar\&Ge harcamaları arasındaki ilişki dikkate alınarak 
yapılmıştır. Fakat gelişmiş ülkelerin ekonomi sistemleri ile gelişmekte olan ve az gelişmiş ülkelerin ekonomilerinde gerçekleşen etkilerin aynı olması mümkün değildir.

Çalışmada ulaşılabilecek en yüksek gözlem değeri kullanılmıştır. Teknolojinin etkisinin bütün ülkeler istihdam oranlarını nasıl etkilediğinin analizini yapabilmek için veri yapısıyla bağlantılı olarak dengesiz panel veri analizi yöntemi tercih edilmiştir. Dengesiz panel verilerini dengeli hale getirebilecek yöntemler mevcuttur. Güriş \& Kızılarslan (2017) çalışmasında dengesiz panel çalışmasını dengeli hale getiren Beklenti Maksimizasyonu (EM) Algoritması $^{1}$ yöntemiyle dengeli ve dengesiz panel regresyonlarını karşılaştırmıştır. Bu karşılaştırma sonucunda regresyon katsayılarının her iki yöntemde de kullanılmasının anlamlı olduğunu bağımlı değişkeni etkileyen bağımsız değişkenlerin katsayıları arasında fark oluşmasına karşın ilişkinin ve etkinin yönünü belirlemede aynı sonuçları verdiğini tespit etmiştir (Güriş \& Kızılarslan, 2017). Çalışmamızda veri eksikliklerini giderme yöntemlerini kullanmak uygun görülmediği için dengesiz panel analizi ile teknolojik değişimin istihdam ve gelir dağılımı üzerindeki etkisini ekonometrik kriterlerle uyumlu ve sağlıklı bir şekilde modellemek amaçlanmıştır.

\subsection{Yöntem ve Veri Seti}

Panel veri analizi çalışmalarında birçok regresyon modeli mevcuttur. Veri setine uygun olabilecek yöntemin belirlenmesi bu sebepten önemlidir. Dengesiz veri setlerinde dengeli panel analizleri için yapılan yöntemlerin hepsi kullanılabilmektedir.

Panel veri analizlerinde diğer ekonometrik modellerde olduğu gibi hata terimleri üzerine varsayımlar regresyon katsayılarının yorumlanabilmesi açısından önem arz etmektedir. Panel çalışmalarında hem zaman serisine ait sapmalar hem de yatay kesit analizlerine ait sapmalar dikkate alınmaktadır. Ayrıca panel verilere ait hata payları çalışmanın sağlıklı sonuçlar vermesi açısından önemlidir. Panel regresyon analizlerinde hata terimlerinin $E(X i t \mu i)=0$ ve $\mathrm{E}(\mathrm{Xit} \lambda \mathrm{i})=0$ ( $\mu \mathrm{i}$ birim etkileri, $\lambda \mathrm{i}$ zaman etkisi) varsayımı altında kurulmaktadır. Birim etkilerin ve zaman etkilerin varlığı durumunda kullanılan özel panel regresyon modelleri de mevcuttur. Genelleştirilmiş En Küçük Kareler (GEKK) yöntemi standart hataların varlığı durumunda kullanılan modellerdendir. GEKK yöntemi aynı zamanda $\mathrm{N}>\mathrm{T}$ durumunun gerçekleştiği mikro panel data modellerinde kullanılabilen bir panel veri tahmincisidir. GEKK yöntemi heteroskedastisite ve otokorelasyonun varlığı durumunda kullanılabilir. Varyans bileşenleri kullanılarak GEKK tahmincisi dengesiz panel veri analizi için uygulanan denklem aşağıdaki gibidir (Baltagi, 2014: 189; Tatoğlu, 2013: 11; Wooldridge, 2015: 492);

$\widehat{\delta}_{G E K K}=\left(Z^{\prime} \Omega^{-1} Z\right)^{-1} Z^{\prime} \Omega^{-1} Y$.

Dengesiz panel veri modellerinde varyans - kovaryans matrisi $(\Omega)$ GEKK için elde edilebilmesi gerekmektedir. $\Omega=I_{n} \Sigma ; \Sigma=\sigma_{\varepsilon}^{2} I_{T}+\sigma_{\mu}^{2} \mathrm{j}_{\mathrm{T}} \mathrm{j}_{\mathrm{T}}^{\prime} \quad$ şeklinde olan denklem $\mathrm{T}$ zaman dönemi her bir birim için farkl1lık göstereceğinden matrislerin diyagonal blokları farklı büyüklükte olacaktır. $\mathrm{Bu}$ sebepten matris uygun bir düzenleme ile $\Omega=\operatorname{diag}\left[\left(T_{i} \sigma_{\mu}^{2}+\sigma_{\varepsilon}^{2}\right) \overline{J_{T i}}+\sigma_{\varepsilon}^{2} E_{T i}\right]$ şeklinde elde edilmektedir (Güriş, 2018: 424). Ayrıca dengesiz panelin tahmininin dengeli panelden tek farkının, dengesiz panel durumunda ağırlıkların her bir birim için mümkün olan zaman serisi boyutunun uzunluğu olduğu söylenebilir (Tatoğlu, 2013: 13).

\footnotetext{
1 Beklenti Maksimizasyonu (EM) Algoritması: Eksik verilere ait serilerin ortalama vektörü ve kovaryans matrislerinden yararlanılarak kurulan regresyonlar ile eksik verileri tahmin etme yöntemidir. Bu yöntem ile veri setindeki eksik verilerin değerleri tahmin edilerek veri seti dengeli hale getirilir.
} 
Modelde kullanılan değişkenler sırasıyla EMP: toplam istihdamı, GDP: ülkelerin milli gelirlerini, LFORCE: işgücünün nüfusa oranını, POPULATION: toplam nüfusu, RD: Ar\&Ge harcamalarını, HTE: yüksek teknoloji ürünlerinin ihracatını ifade etmektedir. Bütün veriler Dünya Bankası Veritabanı'ndan alınarak derlenmiştir.

Tablo 2: Betimsel İstatistikler

\begin{tabular}{|c|c|c|c|c|}
\hline $\begin{array}{l}\text { Değişkenler } \\
\text { (variable) }\end{array}$ & Ortalama(Mean) & $\begin{array}{l}\text { Std. Sapma (Std. } \\
\text { Dev.) }\end{array}$ & En küçük (Min.) & En büyük (Max) \\
\hline EMP & 55.66506 & 9.35728 & 30.601 & 87.817 \\
\hline GDP & $6.14 \mathrm{e}+11$ & $1.83 \mathrm{e}+12$ & $4.87 \mathrm{e}+08$ & $1.94 \mathrm{e}+13$ \\
\hline LFORCE & 60.56912 & 8.542954 & 40.751 & 89.052 \\
\hline POPULATION & $5.99 \mathrm{e}+07$ & $1.92 \mathrm{e}+08$ & 274047 & $1.39 \mathrm{e}+09$ \\
\hline RD & 1.146505 & 9883172 & 0.01498 & 4.42859 \\
\hline HTE & $1.86 \mathrm{e}+10$ & $5.07 \mathrm{e}+10$ & 0 & $5.60 \mathrm{e}+11$ \\
\hline
\end{tabular}

Ülkeler sırasıyla; Cezayir, Arjantin, Avustralya, Avusturya, Belçika, Bosna-Hersek, Brezilya, Bulgaristan, Burkina Faso, Kanada, Şili, Çin, Kolombiya, Kosta Rika, Hırvatistan, Güney Kıbrıs, Çek Cumhuriyeti, Danimarka, Dominik Cumhuriyeti, Ekvador, Mısır, El Salvador, Estonya, Etiyopya, Finlandiya, Fransa, Gabon, Gambiya, Gürcistan, Almanya, Yunanistan, Guatemala, Honduras, Hong Kong-Çin, Macaristan, İzlanda, Hindistan, İran, İrlanda, İsrail, İtalya, Japonya, Kazakistan, Güney Kore, Kuveyt, Letonya, Litvanya, Lüksemburg, Madagaskar, Mali, Malta, Meksika, Moldova, Karadağ, Fas, Mozambik, Hollanda, Yeni Zelanda, Nikaragua, Norveç, Umman, Pakistan, Panama, Paraguay, Filipinler, Polonya, Portekiz, Romanya, Rusya Federasyonu, Sirbistan, Singapur, Slovakya, Slovenya, İspanya, İsveç, İsviçre, Tayland, Tunus, Türkiye, Ukrayna, Birleşik Krallık, ABD, Uruguay, Özbekistan verileri dünya bankasından alınarak derlenmiştir. Gelişmişlik seviyeleri UNDP (2016) raporuna göre ayrılmıştır. Ülkelerin dönemlere göre bazı verileri kriz, iç savaş vb. sebeplerle bulunmadığ gözlenmiştir. Birçok ülke bu sebepten veri setine dahil edilememiştir. Dahil edilen ülkeler veri seti Ar\&Ge harcamaları verileri dikkate alınarak elde edilebilen en çok veriye göre kullanılmıştır. Ar\&Ge harcamaları verileri ile yüksek teknoloji ihracatı verilerinin IMF ve Dünya Bankası gibi merkezlere bütün ülkelerin bildirmemesinden dolayı veri ulaşımında kısıtlar bulunmaktadır. Bu sebeple Ar\&Ge verileri dikkate alınarak ulaşılabilen maksimum veriye ulaşılmaya çalışılmış ve veri seti Ar\&Ge değişkeni verilerinin izin verdiği ölçüde en çok ülke dahil edilerek oluşturulmuştur.

Literatür kullanımı dikkate alındığında regresyon denkleminde bağımlı değişken olarak istihdam, bağımsız değişkenlerde ise kontrol değişkenleri olarak GDP, LFORCE, POPULATION değişkenleri modele eklenmiştir. Teknoloji göstergesi olarak RD (Ar\&Ge) ve HTE (Yüksek teknoloji ihracatı) değişkenleri kullanılmıştır. Çalışmada kullanılacak olan regresyon modeli aşağıdaki gibidir;

Model: $\mathrm{EMP}=\alpha+\beta 1 \log \mathrm{GDP}+\beta 2 \mathrm{LFORCE}+\beta 3 \log \mathrm{POP}+\beta 4 \mathrm{RD}+\beta 5 \log \mathrm{HTE}+\mathrm{e}$

EMP, LFORCE, RD verileri oran olarak kullanıldığı için GDP, POP, HTE verilerinin logaritmaları alınarak veriler arasındaki birim farklılıkları ortadan kaldırılmıştır.

Model denklemleri dengesiz panel kurulumu STATA v.14 programı kullanılarak tahmin edilmiştir. Stata programı diğer programlara göre veri dengesizliklerinde programın algoritmalarının sağladığı avantaj ile boş alanları dikkate almayarak hesaplama 
yapabilmektedir. Denklem içerisinde kullanılan değişkenler, kısıtlamalar dikkate alınarak hesaplama anında eksik veri satırı hesaba dahil edilmeden sonuçlar elde edilebilmektedir. Algoritma esnekliği sayesinde Stata programı yatay kesit ve panel çalışmalarında daha avantajlı olması nedeniyle kabul görmektedir.

\section{Hausman Test}

Panel regresyon analizlerinde kurulacak olan regresyon modeli için karar verilmeden önce hata terimlerinin rassal olup olmadığını anlamak önemlidir. Regresyon modelinde hata terimlerinin bağımsız değişkenler ile ilişkisi bulunuyorsa sabit etkili tahmin yöntem sonuçları tutarlı olurken, tesadüfi etkiler tahmincileri aynı şekilde tutarlı olmayacaktır. Eğer tesadüfi etkiler modelindeki hata terimleri bileşenlerinin bağımsız değişken ile ilişkisi bulunmuyorsa sabit ve tesadüfi etkili yöntemlerin tahmincileri tutarlı olmasına rağmen tesadüfi etkiler yöntemlerindeki hesaplamalar asimptotik olarak etkin olacak ve tesadüfi etkilerin dikkate alınarak tahmini daha uygun olacaktır (Güriş, 2018: 39).

Hausman (1978) testi panel veri setindeki hata terimlerinin bileşenlerinin bağımsız değişkenler ile ilişkisinin rassal ya da sabit olduğunun test edilebilmesi için kullanılan yöntemdir. Bunun için öncelikle sabit etkili ve rassal etkili modellerle regresyon tahmini yapılarak hata terimleri hesaplanarak ilişki incelenir.
$\mathrm{H}_{0}: \mathrm{E}\left(\mathrm{X}^{\prime} \quad \mu \mathrm{i}\right)=0$
$\mathrm{H}_{1}: \mathrm{E}\left(\mathrm{X}^{\prime}\right.$
$\mu \mathrm{i}) \neq 0$

$\mathrm{H}_{0}$ hipotezi bağımsız değişkenler ve hata terimleri arasında ilişkinin olmadığını varsaymaktadır. $\mathrm{H}_{1}$ hipotezi ise bazı değişkenler ile hata terimlerinin ilişkili olduğunu varsaymaktadir. $\mathrm{H}_{0}$ hipotezinin reddedilememesi durumunda rassal etkili GEKK tahmincilerinin sonuçları tutarlı olacaktır.

Tablo 3: Hausman Testi Bütün Ülke Grupları

\begin{tabular}{cc}
$\mathbf{C h i}^{2}(\mathbf{4})$ & ${\text { Prob }>\mathbf{c h i}^{2}}^{{ }^{2}}$ \\
\hline $\mathbf{0 . 0 9}$ & 0.9991 \\
\hline
\end{tabular}

Genel olarak tüm ülke grupları ile kurulan regresyon modelleri ile yapılan test istatistikleri sonucunda (Tablo 3) $\mathrm{H}_{0}$ hipotezi reddedilememektedir. Bağımsız değişkenlerin hata terimleri ile ilişkisinin olmadığ 1 kabul edilmiştir. Bu durumda GEKK tahmincisi sonuçları sapmasız ve tutarlı olacaktır.

Tablo 4: Hausman Testi Gelişmiş Ülkeler

$\mathrm{Chi}^{2}(4) \quad$ Prob $>\mathrm{Chi}^{2}$

$\mathbf{1 4 7 0 . 4 5} 0.0000$

Verilerin gelişmiş ülkeler bazında kısıtlanarak yapılan regresyon modellemesine göre yapılan Hausman Testi sonuçları Tablo 4.'de verilmiştir. Bu tabloya göre $\mathrm{H}_{0}$ hipotezi red edilmekte bağımsız değişkenlerin bazılarının hata terimleriyle ilişkili olduğu varsayımı kabul edilmektedir.

Tablo 5: Hausman Testi Gelişmekte Olan Ülkeler $\mathrm{Chi}^{2}(4)$ Prob $>$ chi $^{2}$

$6.96 \quad 0.2234$


Hausman Testini (Tablo 5) gelişmekte olan ülke grupları için uyguladığımızda ise yine H0 hipotezinin reddedilemediği ve bağımsız değişkenlerin hata terimleriyle ilişkili olmadığı kabul edilmektedir.

Hausman Testi sonuçlarına göre tesadüfi etkiler varsayımları karşılanmaktadır ve GEKK tahmincileriyle elde edilen sonuçların yansız ve tutarlı olduğu kabul edilmektedir. Bu nedenle GEKK tahmincisi kullanılarak regresyon modelleri kurulacaktır.

Ayrıca regresyon modelimiz (N) birim sayısı büyük (T) zaman serisi küçük olan mikro panel özelliğine sahiptir. Bu sebepten Birim Kök, Heteroskedastisite, Otokorelasyon ve Birimler Arası Korelasyon testleri yapılmadan doğrudan regresyon analizi gerçekleştirilmiştir.

\subsection{GEKK Yöntemi Regresyon Analizleri}

Regresyon tablosu (Tablo 6) rassal etkiler yöntemleri ile yapılan testleri içermektedir. FE (Fixed Effect), sabit birim etkilere müsade eden grup içi tahminci parametrelerini vermektedir. Pesaran ve Smith (1995) bu tahmin metodunda parametre tahmincilerinin sapmalı olduğunu ifade etmişlerdir. İkinci sütunda ise tesadüfi etkiler için genelleştirilmiş en küçük kareler yöntemi RE (Random Effect), yine GEKK yöntemi gruplar arası etkileri dikkate alan tahmin yöntemi BE (Between Effect), en çok olabilirlik tahmincisi olarak MLE (Maximum Likelihood Estimation) yöntemi ile yapılan test sonuçlarını göstermektedir.

Tablo 6: Dengesiz Panel Regresyon Analizleri, EMP Bağımlı Değişken

\begin{tabular}{|c|c|c|c|c|c|c|}
\hline 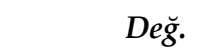 & FE & RE & BE & MLE & ROBUST & SCC \\
\hline Cons & 17.9033 & $-20.2965^{* * *}$ & $-15.7781^{* *}$ & $-20.3123^{* * *}$ & $-20.2965^{* * *}$ & $-20.2965^{* * *}$ \\
\hline $\log G D P$ & $1.0830^{* * *}$ & $0.8790^{* * *}$ & 0.2730 & $0.8764^{* * *}$ & $0.8790^{* * *}$ & $0.8790^{* * *}$ \\
\hline LFORCE & $1.0651^{* * *}$ & $1.0595^{* * *}$ & $1.0623^{* * *}$ & $1.0598^{* * *}$ & $1.0595^{* * *}$ & $1.0595^{* * *}$ \\
\hline $\log P O P$ & $-3.4407^{* * *}$ & $-0.7971^{* * *}$ & -0.2285 & $-0.7898^{* * *}$ & $-0.7971^{* * *}$ & $-0.7971^{*}$ \\
\hline$R D$ & $-1.1278^{* * *}$ & $-1.0304^{* * *}$ & -0.2005 & $-1.0259^{* * *}$ & $-1.0304^{* *}$ & $-1.0304^{* * *}$ \\
\hline $\log H T E$ & $0.1644^{* *}$ & $0.1742^{* *}$ & 0.1995 & $0.1744^{* *}$ & 0.1742 & $0.1742^{*}$ \\
\hline$R^{2}$ within & 0.6011 & 0.5967 & 0.5801 & & 0.5966 & \\
\hline$R^{2}$ between & 0.7331 & 0.9219 & 0.9267 & & 0.9219 & \\
\hline$R^{2}$ overall & 0.6952 & 0.9101 & 0.9168 & & 0.9101 & \\
\hline Sigma_u & 5.0818 & 2.5635 & & 2.5208 & 2.5635 & 2.5635 \\
\hline Sigma_e & 1.3979 & 1.3979 & & 1.4032 & 1.3979 & 1.3979 \\
\hline Rho & 0.9296 & 0.7708 & & 0.7634 & 0.7708 & 0.7708 \\
\hline$R^{2}$ & & & & & & 0.9101 \\
\hline F/Prob & & & & & & 0.000 \\
\hline Gözlem sayısı & 1194 & 1194 & 1194 & 1194 & 1194 & 1194 \\
\hline Gözlem grubu & 81 & 81 & 81 & 81 & 81 & 81 \\
\hline
\end{tabular}

Not: Anlamlılık seviyesi *: \%10,**: \%5, ${ }^{* * *}$ : \%1 olarak ifade etmektedir.

ROBUST Heteroskedastisite ve Otokorelasyon sorunlarının varlığ durumunda, SCC (Driscoll and Kraay (1998)) ise Otokorelasyon, Heteroskedastisite ve birimler arası korelasyon sorunları durumunda hata düzeltme modelleri olarak kullanılmıştır (Tatoğlu, 2013: 21).

Tablo 6 verileri Model 1 regresyon denkleminin kurulduğu 6 farklı rassal etkiler tahmin yöntemi kullanılarak elde edilmiştir. Tablo 6 incelendiğinde RE, ROBUST (hata düzeltme modeli) ve SCC (Driscoll and Kraay (1998)) modellerinde değişken katsayılarının, R2, sigma, rho değerlerinin aynı olduğu görülmektedir. Yalnızca nüfus ve yüksek teknoloji ihracatı verilerinin SCC yönteminde olasılık değerlerinin \%1 anlamlılık düzeyinden $\% 5$ anlamlılık 
düzeyine düştüğü görülmektedir. Hausman testine göre grup içi tahmincilerinin verileri tutarlı olamayacağından Tablo 7 verileri de dikkate alınarak regresyon analizinde RE (Rassal Etkiler) Genelleştirilmiş En Küçük Kareler (GEKK) yöntemi kullanılarak devam edilmesine karar verilmiştir.

Tablo 7: Dengesiz Panel Regresyon (GEKK) Analizleri, EMP Bağımlı Değişken

\begin{tabular}{|c|c|c|c|c|}
\hline Bă̆ımsız Dĕ̆. & Genel & G1 & G2 & G3 \\
\hline Cons & $\begin{array}{l}-20.2965^{\text {***}} \\
(-6.29)\end{array}$ & $\begin{array}{l}-17.0438^{* * *} \\
(-5.08)\end{array}$ & $\begin{array}{l}-29.8693^{* * *} \\
(-6.10)\end{array}$ & $\begin{array}{l}7.7724 \\
(0.25)\end{array}$ \\
\hline $\log G D P$ & $\begin{array}{l}0.8790^{* * *} \\
(7.12)\end{array}$ & $\begin{array}{l}0.8868^{* * *} \\
(4.76)\end{array}$ & $\begin{array}{l}0.9069^{* * *} \\
(5.93)\end{array}$ & $\begin{array}{l}-2.6054 \\
(-0.83)\end{array}$ \\
\hline LFORCE & $\begin{array}{l}1.0595^{* * *} \\
(49.72)\end{array}$ & $\begin{array}{l}1.0611^{* * *} \\
(33.50)\end{array}$ & $\begin{array}{l}1.0806^{* * *} \\
(37.49)\end{array}$ & $\begin{array}{l}0.8507^{* * *} \\
(5.46)\end{array}$ \\
\hline $\log P O P$ & $\begin{array}{l}-0.7971^{* * *} \\
(-4.13)\end{array}$ & $\begin{array}{l}-1.0783^{* * *} \\
(-5.04)\end{array}$ & $\begin{array}{l}-0.3771 \\
(-1.31)\end{array}$ & $\begin{array}{l}3.6535 \\
(1.08)\end{array}$ \\
\hline$R D$ & $\begin{array}{l}-1.0304^{* * *} \\
(-5.81)\end{array}$ & $\begin{array}{l}-0.6765^{* * *} \\
(-3.45)\end{array}$ & $\begin{array}{l}-1.3421^{* *} \\
(-3.14)\end{array}$ & $\begin{array}{l}-18.6687^{* *} \\
(-2.76)\end{array}$ \\
\hline $\log H T E$ & $\begin{array}{l}0.1742^{* *} \\
(2.93)\end{array}$ & $\begin{array}{l}0.1795^{*} \\
(1.77)\end{array}$ & $\begin{array}{l}0.2268^{* * *} \\
(3.40)\end{array}$ & $\begin{array}{l}0.0433 \\
(0.06)\end{array}$ \\
\hline$R^{2}$ within & 0.5967 & 0.4881 & 0.7474 & 0.3427 \\
\hline$R^{2}$ between & 0.9219 & 0.9451 & 0.9437 & 0.8529 \\
\hline$R^{2}$ overall & 0.9101 & 0.8881 & 0.9343 & 0.7952 \\
\hline Sigma_u & 2.5635 & 1.5487 & 2.3995 & 0 \\
\hline Sigma_e & 1.3979 & 1.5086 & 1.1556 & 0.6149 \\
\hline Rho & 0.7708 & 0.5131 & 0.8117 & 0 \\
\hline Gözlem sayısı & 1194 & 752 & 404 & 38 \\
\hline Gözlem grubu & 81 & 44 & 31 & 6 \\
\hline
\end{tabular}

Not: Anlamlılık seviyesi *: \%10,**: \%5, ***: \%1 olarak ifade etmektedir. Parantez içindeki değerler (Z) katsayısını içermektedir.

Tablo 7 verileri Genel sütunu 81 ülkenin tamamını, G1 sütunu gelişmiş ülkeler UNDP (Birleşmiş Milletler Kalkınma Programı) kriterlerine göre 44 ülke verilerini, G2 sütununda gelişmekte olan ülkeler ve G3 sütununda ise az gelişmiş 6 ülke kısıtlaması ile kurulan Model 1 denklem sonuçlarını vermektedir. G1, G2 ve G3 ülkeleri ile yapılan regresyon tahminlerinde $\mathrm{R}^{2}$ değerlerinin gurup içi (within) tahminleri hariç yüksek açıklayıcılığa sahip olduğu görülmektedir. Buna göre $\mathrm{R}^{2}$ (overall) değerleri tüm ülkeler için (Genel) \%91, gelişmiş ülkeler için (G1) \%88, gelişmekte olan ülkeler için (G2) \%93, az gelişmiş ülkeler için (G3) ise \%79 açıklayıcı olduğu görülmektedir. $\mathrm{R}^{2}$ testi sonuçlarına göre modellerimiz istihdamı açıklamada istatistiki olarak anlamlı bulunmuştur.

Tablo 7 verilerinde toplam istihdam ile bağımsız değişkenlerin katsayılarının ilişkileri literatürdeki teorilerle uygun olduğu görülmektedir. GDP ile istihdam ilişkisinin denkleme katılan ülkelerin tamamında pozitif, gelişmiş ve gelişmekte olan (G1 ve G2) ülkeler için pozitif bir etkiye sahip olduğu görülmektedir. Az gelişmiş ülkeler (G3) için ise elde edilen negatif değer \%10 anlamlılık seviyesinde olmadığından büyümenin istihdam üzerinde bir etkisinin bulunmadığı söylenebilir. Bu durumda genel olarak ekonomik büyümenin istihdamı arttırıcı bir etkisinin olduğunu, gelişmiş ülkeler için \%1'lik bir büyümenin \%0.88, gelişmekte olan ülkeler için ise yaklaşık olarak \%0.91'lik bir istihdam artışı sağladığı görülmektedir. Az gelişmiş ülkelerde büyümenin istihdam üzerinde anlamlı bir etkisinin bulunmadığ 1 anlaşılmaktadır. Bunun sebebi ekonomideki aksaklıklar, nüfus artış hızının yüksek olması, 
istihdam üretme konusunda en verimli olan sektörlerin (inşaat ve hizmetler sektörleri) istihdama katılımı karşılayabilecek yeterlilikte iş alanları oluşturamaması, teknolojik gelişmeler sonucunda emek verimliliğinin artışı gibi etkenlerden dolayı büyümenin yeterli istihdam oluşturamaması gibi nedenlerdir (Kara \& Duruel, 2005: 369).

Tablo 7 verileri incelendiğinde yine nüfus değişkeninin istihdam ile olan ilişkisinin gelişmiş ve gelişmekte olan ülkelerde negatif az gelişmiş olan ülkelerde pozitif olduğu görülmektedir. Gelişmiş ve gelişmekte olan ülkelerde nüfusun artışının istihdam ile ilişkisinin negatif olması, emeğin az gelişmiş ülkelere kıyasla daha yüksek ücretlerden fiyatlanması olarak gösterilebilir. Gelişmiş ve gelişmekte olan ülkelerde emek gücünün fiyatı sendikalaşmalar sayesinde korunmaktayken az gelişmiş ülkelerde sendikalaşma yeteri seviyede sağlanamamaktadır. Ar\&Ge (RD) harcamalarının genel olarak istihdama etkisinin negatif olduğu görülmektedir. Ar\&Ge harcamaları (RD) katsayılarının tüm ülkeler ve gelişmiş ülkeler için \%1 seviyesinde anlamlı, gelişmekte olan ve az gelişmiş ülkeler için ise \%5 seviyesinde anlamlı olduğu görülmektedir. Ar\&Ge harcamalarındaki (RD) \%1 oranında bir değişim sonucu gelişmiş, gelişmekte olan ve az gelişmiş ülkeler için katsayıların sırasıyla \%0.67, \%1.34 ve \%18.66 oranında istihdam azalışına neden olduğu tespit edilmiştir.

Teknoloji ve istihdam ilişkisini dikkate alan literatürdeki diğer çalışmalar seçilmiş bazı gelişmiş olan ülkelerin dikkate alındığı çalışmaları içermektedir. Bu çalışma onlardan farklı olarak 44 gelişmiş ülke ile elde edilebilecek en yakın ilişki tespit edilmeye çalışılmıştır. Gelişmiş ülkeler ile ilgili olarak yapılmış olan literatür çalışmalarının aksine Ar\&Ge (RD) harcamaları sonuçları dikkate alındığında teknolojinin istihdamı azaltıcı bir etki gösterdiği anlaşılmaktadır. Gelişmekte olan ve az gelişmiş ülkelerin katsayılarının yüksek olması teknolojik değişim süreçlerinde ortaya çıkan istihdam hareketliliğini canlı tutabilecek iş alanlarının ihtiyaca cevap veremediğini ortaya çıkarmıştır. Yüksek teknoloji ürünleri ihracatının katsayıları tüm ülkeler için \%5 seviyesinde anlamlı, gelişmiş ülkelerde (G1 sütunu) $\% 10$, gelişmekte olan ülkelerde (G2 sütunu) \%1 seviyesinde anlamlıdır. Az gelişmiş ülkeler (G3 sütunu) için ise \%10 seviyesinde anlamlılık içermediği için G3 ülkelerinde yüksek teknoloji ürünleri ihracatının istihdam üzerinde bir etkisinin bulunmadığı söylenebilir. Bunun sebebi ise az gelişmiş ülkelerin teknoloji üretimini yaygınlaştıramaması ve teknoloji bilgi birikiminin yeterli seviyede olmamasıdır. Ar\&Ge harcamalarının (RD) aksine yüksek teknoloji ihracatı (HTE) değişkeninde ortaya çıkan 1 birimlik bir değişimin istihdamı genel olarak \%0.17 arttırdığı gözlenmektedir. İstihdamı arttırıcı etkisi gelişmiş ülkelerde yaklaşık $\% 0.18$ ve gelişmekte olan ülkelerde \%0.22 olarak gerçekleşmiştir. Vivarelli'nin çalışmasındakine benzer şekilde Şekil 2 inovasyon gelişim süreci tablosuna uyumlu sonuçlar elde edilmiştir. Yüksek teknoloji ihracatını (HTE) yeni teknolojik ürün üretimi verisi Ar\&Ge harcamalarını (RD) ise teknoloji değişimi süreci olarak dikkate aldığımızda, teknolojik ürün üretiminde meydana gelen bir artışın istihdam oranı üzerinde arttırıcı etkisi olduğu regresyon sonuçları ile de doğrulandığı görülmektedir. Ürün üretiminin istihdamı arttırmasının yanında teknolojik değişim ile üretim sürecinde ortaya çıkan emek tasarrufu ile istihdamın azaldığ 1 tablo 7 verileriyle daha net anlaşılmaktadır.

Dördüncü Sanayi Devrimi kavramı 2011 yılında ortaya çıkmıştır. 2011 yılı ve sonrasında Avrupa ve gelişmiş ülkelerin birçoğu Endüstri 4.0 konusunda çalışacak komisyonlar oluşturmuş ve inovatif çalışmaları destekleyici politikalar gerçekleştirmiştir. Bu sebepten regresyon modellerinden model üzerinde tarih aralığı dikkate alınarak iki ayrı veri seti 
oluşturulmuş ve bu setler üzerinden yeniden regresyon analizi yapılarak 2011 sonrası teknolojik değişimin etkisi gözlenmeye çalışılmıştır.

Tablo 8: Endüstri 4.0 Öncesi ve Sonrası Dönemler İçin Dengesiz Panel Regresyon (GEKK)

\begin{tabular}{|c|c|c|c|}
\hline Değ. & $1998-2017$ & $\begin{array}{l}1998-2010 \\
4.0 \text { 'dan önce }\end{array}$ & $\begin{array}{l}2011-2017 \\
4.0^{\prime} \text { dan sonra }\end{array}$ \\
\hline Cons & $\begin{array}{l}-20.2965^{\text {*** }} \\
(-6.29)\end{array}$ & $\begin{array}{l}-22.3493^{* * *} \\
(-6.62)\end{array}$ & $\begin{array}{l}-25.2532^{* * *} \\
(-5.34)\end{array}$ \\
\hline $\log G D P$ & $\begin{array}{l}0.8790^{* * *} \\
(7.12)\end{array}$ & $\begin{array}{l}1.0785^{* * *} \\
(7.76)\end{array}$ & $\begin{array}{l}0.3497 \\
(1.24)\end{array}$ \\
\hline LFORCE & $\begin{array}{l}1.0595^{* * *} \\
(49.72)\end{array}$ & $\begin{array}{l}1.0485^{* * *} \\
(45.52)\end{array}$ & $\begin{array}{l}1.1765^{* * *} \\
(35.06)\end{array}$ \\
\hline $\log P O P$. & $\begin{array}{l}-0.7971^{* * *} \\
(-4.13)\end{array}$ & $\begin{array}{l}-0.8714^{* * *} \\
(-4.38)\end{array}$ & $\begin{array}{l}-0.1186 \\
(-0.40)\end{array}$ \\
\hline$R D$ & $\begin{array}{l}-1.0304^{* * *} \\
(-5.81)\end{array}$ & $\begin{array}{l}-0.8184^{* * *} \\
(-3.66)\end{array}$ & $\begin{array}{l}-0.6616^{* *} \\
(-2.47)\end{array}$ \\
\hline $\log H T E$ & $\begin{array}{l}0.1742^{* * *} \\
(2.83)\end{array}$ & $\begin{array}{l}0.1150^{*} \\
(1.65)\end{array}$ & $\begin{array}{l}0.1598^{*} \\
(1.77)\end{array}$ \\
\hline$R^{2}$ within & 0.5967 & 0.6318 & 0.6201 \\
\hline$R^{2}$ between & 0.9219 & 0.9241 & 0.9206 \\
\hline$R^{2}$ overall & 0.9101 & 0.9217 & 0.9039 \\
\hline Sigma_u & 2.5635 & 2.5748 & 2.5029 \\
\hline Sigma_e & 1.3979 & 1.1567 & 0.7562 \\
\hline Rho & 0.7708 & 0.8321 & 0.9163 \\
\hline Gözlem sayısı & 1194 & 810 & 369 \\
\hline Gözlem grubu & 81 & 79 & 68 \\
\hline Wald chi²(5) & 2571.43 & 2173.03 & 1245.42 \\
\hline Prob $>c h i^{2}$ & 0.0000 & 0.0000 & 0.0000 \\
\hline
\end{tabular}

Not: Anlamlılık seviyesi *: \%10,**: \%5, ***: \%1 olarak ifade etmektedir. Parantez içindeki değerler (Z) katsayısını içermektedir.

Tablo 8 verilerinde 81 ülke dikkate alınarak 1998 - 2010 yılları arasında yani Endüstri 4.0 öncesi ve 2011 - 2017 yılları arasında Endüstri 4.0 sonrası olarak iki ayrı dönemde toplam istihdam üzerinde teknolojinin etkisi tespit edilmek istenmiştir. Tablo 8 verilerinde tarih ayrımı sebebiyle 1998 - 2017 yıllarında 81 ülke ile elde edilen gözlem sayısının 1998 - 2010 yılları arasında 79 ülke, 2011 - 2017 yılları arasında ise 68 ülke grubuna düştüğü görülmektedir. Bunun sebebi bazı ülkelerin 2010 öncesinde Ar\&Ge harcamaları bilgilerini paylaşmamış olması, 2011 - 2017 yılları arasındaki grup farklılı̆̆ının ise yaşanan siyasi olaylar ve iç savaşlar gibi sebepler nedeniyle veri paylaşımlarının çok düzensiz olmasıdır. Özellikle 2011 - 2017 dönemine ait verilerdeki eksikliklerden dolayı hesaplamaların sapmalı olmaması için bazı ülkeler gruptan çıartılmıştır.

Tablo 8 regresyon tahminleri $\mathrm{R}^{2}$ (overall) değerleri üç regresyon içinde $\% 90$ ve üzeri sonuçlar vermiştir. 1998-2017 yılları dikkate alınan regresyon $\mathrm{R}^{2}$ değeri \%91, 1998-2010 yılları verileri dikkate alınan regresyon $\mathrm{R}^{2}$ değeri \%92, 2011-2017 yılları verileri ile yapılan regresyon sonuçlarına göre ise $\mathrm{R}^{2}$ değeri \%90 olduğu görülmektedir. Wald chi ${ }^{2}$ testi sonuçları probility değerleri \%1 anlamlılık seviyesindedir. $\mathrm{R}^{2}$ ve wald chi $^{2}$ testleri dikkate alındığında regresyon sonuçlarını yorumlamak istatistiki olarak anlamlıdır.

Büyüme (GDP) ve toplam istihdam (EMP) arasında 1998 - 2017 ve 1998 - 2010 yıllarında \%1 seviyesinde anlamlı ve pozitif ilişki bulunmuştur. 2011 - 2017 yıllarında ise büyüme ile toplam 
istihdam arasında anlamlı bir ilişkinin bulunmadığı görülmektedir. Genel olarak 1998 - 2017 döneminde büyümede ortaya çıkacak olan 1 birimlik bir artışın istihdam üzerinde yaklaşık \%0.88 oranında bir artışa sebep olduğu, 1998 - 2010 yıllarında ise yaklaşık olarak \%1.08 oranında artış sergilediği görülmektedir. İşgücü (LFORCE) ve istihdam arasında her üç dönem için \%1 seviyesinde anlamlı ve pozitif sonuçlar elde edilmiştir. İşgücünde ortaya çıkacak olan \%1'lik bir artış için 1998 - 2017 döneminde \%1.06, 1998 - 2010 yıllarında \%1.05 ve 2011 - 2017 yılları arasında ise \%1.18 oranında bir artışa sebep olmuştur. Nüfus (POP) ile istihdam arasındaki ilişki \%1 seviyesinde negatif ve anlamlı sonuçlar göstermektedir. Nüfusta ortaya çıkacak olan 1 birimlik bir artışta 1998 - 2017 yılları arasında \%0.80, 1998 - 2010 yıllarında \%0.87, 2011 - 2017 yıllarında ise \%0,11 oranında azalışa neden olduğu görülmektedir. Nüfus ve istihdam arasındaki ilişkinin son yıllarda zayıfladığı sonucuna ulaşılmaktadır.

Tablo 8. incelendiğinde 1998 - 2017 yılları arasında Ar\&Ge (RD) harcamaları ve yüksek teknoloji ürünler ihracatı katsayılarının \%1 seviyesinde anlamlı olduğu görülmektedir. Endüstri 4.0 öncesi Ar\&Ge harcamaları (RD) \%1 düzeyinde anlamlı iken sonrası için \%5 seviyesinde anlamlı bir sonuç elde edilmiştir. Yüksek teknolojili ürün ihracatında (HTE) ise Endüstri 4.0 öncesi ve sonrası için \%10 seviyesinde anlamlı sonuçlar elde edilmiştir. 1998 2017 yılları Ar\&Ge harcamaları (RD) dikkate alındığında \%1 oranındaki bir değişimde istihdamda \%1.03 azalış gözlenmekte iken Endüstri 4.0 öncesinde \%0.87, Endüstri 4.0 sonrasında \%0,66 azalış tespit edilmiştir. Yüksek teknoloji ürün ihracatı (HTE) verilerinde ise toplam istihdam üzerinde 1998 - 2017 döneminde \%0.17 pozitif katkı gözlenirken Endüstri 4.0 öncesi $\% 0.11$, sonrasında ise $\% 0.15^{\prime}$ lik pozitif bir katkının olduğu görülmektedir. Bu durumda süreç inovasyonun negatif etkisinin Endüstri 4.0 sonrasında azaldığı, yüksek teknoloji ürün üretiminin pozitif etkisinin ise artış gösterdiği söylenebilir.

Endüstri 4.0 öncesi ve sonrası ayrımının ülkelerin gelişmişlik seviyelerine göre incelemek için kurulan regresyon sonuçları Tablo 9 ve 10 verilerinde görülmektedir. Toplam istihdam bağımlı değişken olarak kullanılan regresyon sonuçları 1998 - 2010 yılları kısıtı ile Tablo 9.'da verilmiştir. Diğer regresyon sonuçlarında olduğu gibi buradaki ayrımda $\mathrm{R}^{2}$ değerlerinin yüksek değerler içerdiği görülmektedir. Gelişmiş ülkeler (G1) için yapılan regresyon tahmini $\mathrm{R}^{2}$ (overall) değerinin \%91, gelişmekte olan ülkeler regresyon tahmini değeri \%93, az gelişmiş ülkeler için ise $\% 74$ açıklayıcılığa sahiptir. Wald chi ${ }^{2}$ testleri prob değerleri \%1 seviyesinde anlamlı olduğu görülmektedir. İstatistiki olarak her üç regresyon analizi yorumlanabilir.

Büyüme (GDP) ve istihdam ilişkisi gelişmiş (G1) ve gelişmekte olan (G2) ülkelerde \%1 seviyesinde anlamlı ve pozitif etkiye sahip olduğu görülmektedir. Az gelişmiş ülkeler (G3) açısından ise anlamlı bir ilişki tespit edilememiştir. Büyümede ortaya çıkacak olan 1 birimlik bir artışın gelişmiş ülkelerde \%1.11, gelişmekte olan ülkelerde ise \%1.23 oranında istihdam artışına neden olduğu, az gelişmiş olan ülkelerde ise anlamlı bir etkisinin bulunmadığ anlaşılmaktadır. İşgücünün (LFORCE) istihdama etkisi ise gelişmiş ülkelerde negatif ve \%1 seviyesinde anlamlı, gelişmekte olan ülkeler ve az gelişmiş ülkelerde ise \%1 seviyesinde anlamlı ve pozitif ilişki tespit edilmiştir. İşü cünde ortaya çıkacak olan \%1 oranındaki bir artış gelişmiş ülkeler istihdamında \%1.07 oranında bir azalışa neden olmaktayken gelişmekte olan ülkelerde \%1.12, az gelişmiş ülkelerde ise \%0.76 oranında artış sağladığ 1 görülmektedir. Gelişmiş ülkeler ve az gelişmiş ülkeler açısından Ar\&Ge harcamaları (RD) \%5 seviyesinde anlamlı etkilerin bulunduğunu göstermektedir. Gelişmekte olan ülkelerde ise Ar\&Ge 
harcamaları ve yüksek teknoloji ürün ihracatının (HTE) istihdam üzerinde anlamlı bir etkisinin bulunmadığı gözlenmektedir. Ayrıca gelişmiş ve az gelişmiş ülkeler için yüksek teknoloji ürün ihracatının katsayılarının anlamlı olmadığı, 1998 - 2010 yıllarında istihdam üzerinde anlamlı bir ilişkinin bulunmadığı söylenebilir.

Tablo 9: Endüstri 4.0 Öncesi 1998 - 2010, Dengesiz Panel Regresyon (GEKK) Analizleri, EMP Bağımlı Değişken

\begin{tabular}{|c|c|c|c|}
\hline Dĕ̆. & G1 & G2 & G3 \\
\hline Cons & $\begin{array}{l}-16.6888^{* * *} \\
(-5.08)\end{array}$ & $\begin{array}{l}-34.0462^{* * *} \\
(-6.12)\end{array}$ & $\begin{array}{l}34.3254 \\
(0.95)\end{array}$ \\
\hline $\log G D P$ & $\begin{array}{l}1.1140^{* * *} \\
(6.08)\end{array}$ & $\begin{array}{l}1.2343^{* * *} \\
(5.81)\end{array}$ & $\begin{array}{l}-4.1024 \\
(-1.24)\end{array}$ \\
\hline LFORCE & $\begin{array}{l}-1.0297^{* * *} \\
(32.46)\end{array}$ & $\begin{array}{l}1.1217^{* * *} \\
(31.42)\end{array}$ & $\begin{array}{l}0.7666^{* * *} \\
(4.78)\end{array}$ \\
\hline $\log P O P$. & $\begin{array}{l}-1.3081^{* * *} \\
(-6.42)\end{array}$ & $\begin{array}{l}-0.6443^{*} \\
(-1.96)\end{array}$ & $\begin{array}{l}4.0112 \\
(1.17)\end{array}$ \\
\hline$R D$ & $\begin{array}{l}-0.5667^{* *} \\
(-2.56)\end{array}$ & $\begin{array}{l}-0.4890 \\
(-0.81)\end{array}$ & $\begin{array}{l}-19.3787^{* *} \\
(-2.54)\end{array}$ \\
\hline $\log H T E$ & $\begin{array}{l}0.1527 \\
(1.50)\end{array}$ & $\begin{array}{l}0.1120 \\
(1.12)\end{array}$ & $\begin{array}{l}0.6022 \\
(0.69)\end{array}$ \\
\hline$R^{2}$ within & 0.5561 & 0.7379 & 0.1034 \\
\hline$R^{2}$ between & 0.9537 & 0.9350 & 0.8803 \\
\hline$R^{2}$ overall & 0.9176 & 0.9329 & 0.7939 \\
\hline Sigma_u & 1.4740 & 2.4473 & 0 \\
\hline Sigma_e & 1.2002 & 1.0617 & 0.4943 \\
\hline Rho & 0.6013 & 0.8416 & 0 \\
\hline Gözlem sayısı & 507 & 272 & 31 \\
\hline Gözlem grubu & 44 & 29 & 6 \\
\hline Wald chi2(5) & 1330.32 & 47.16 & 96.28 \\
\hline Prob $>c h i^{2}$ & 0.0000 & 0.0000 & 0.0000 \\
\hline
\end{tabular}

Not: Anlamllık seviyesi *: \%10,**: \%5, ${ }^{* * *}$ \%1 olarak ifade etmektedir. Parantez içindeki değerler (Z) katsayısını içermektedir.

Ar\&Ge harcamalarında (RD) \%1 oranında ortaya çıkan bir artışın etkisi toplam istihdam üzerinde \%0.56 ve az gelişmiş ülkelerde \%19.37 azalışa neden olmaktadır. Aynı dönemde yüksek teknoloji ürünler ihracatı bütün ülkeler açısından anlamlı bir etkiye sahip değildir. HTE bağımsız değişkeninde Tablo 8' deki Endüstri 4.0 öncesi için bulunan istihdam üzerindeki pozitif etkiye rağmen aynı dönemde gelişmişlik seviyelerine göre incelendiğinde anlamlı bir etki bulunamamıştır. Teknoloji ürün ihracatı genel olarak dünya ülkeleri istihdam düzeyinde pozitif etkiye sebep olsa da ülke grupları açısından anlamlı bir artışın bulunmadığı sonucuna ulaşılmıştır. Bu durum teknoloji açısından gelişmiş ülkelerde bile teknoloji üretme ve geliştirme açısından farklılıklar bulunduğunu göstermektedir. 
Tablo 10: Endüstri 4.0 Sonrası 2011 - 2017, Dengesiz Panel Regresyon (GEKK) Analizleri, EMP Bağımlı Değişken

\begin{tabular}{|c|c|c|}
\hline 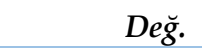 & G1 & G2 \\
\hline Cons & $\begin{array}{l}-36.9446^{* * *} \\
(-5.72)\end{array}$ & $\begin{array}{l}-11.8584 \\
(-1.57)\end{array}$ \\
\hline $\log G D P$ & $\begin{array}{l}0.5376 \\
(1.08)\end{array}$ & $\begin{array}{l}-0.2966 \\
(-0.70)\end{array}$ \\
\hline LFORCE & $\begin{array}{l}1.2943^{* * *} \\
(21.51)\end{array}$ & $\begin{array}{l}1.1191^{* * *} \\
(25.37)\end{array}$ \\
\hline $\log P O P$ & $\begin{array}{l}-0.8670^{*} \\
(-1.66)\end{array}$ & $\begin{array}{l}0.3763 \\
(0.71)\end{array}$ \\
\hline$R D$ & $\begin{array}{l}-1.0152^{* * *} \\
(-3.25)\end{array}$ & $\begin{array}{l}1.2707 \\
(1.63)\end{array}$ \\
\hline $\log H T E$ & $\begin{array}{l}0.7029^{* * *} \\
(3.81)\end{array}$ & $\begin{array}{l}0.0377 \\
(0.44)\end{array}$ \\
\hline$R^{2}$ within & 0.5938 & 0.7851 \\
\hline$R^{2}$ between & 0.8767 & 0.9280 \\
\hline$R^{2}$ overall & 0.8484 & 0.9305 \\
\hline Sigma_u & 2.3774 & 2.8636 \\
\hline Sigma_e & 0.7887 & 0.5654 \\
\hline Rho & 0.9009 & 0.9575 \\
\hline Gözlem sayısı & 240 & 126 \\
\hline Gözlem grubu & 42 & 25 \\
\hline Wald $\operatorname{chi}^{2}(5)$ & 549.97 & 662.72 \\
\hline Prob $>c h i^{2}$ & 0.0000 & 0.0000 \\
\hline
\end{tabular}

Not: Anlamlılık seviyesi *: \%10,**: \%5, ***: \%1 olarak ifade etmektedir. Parantez içindeki değerler (Z) katsayısını içermektedir.

Tablo 10 ise Endüstri 4.0 sonrası dönem olan 2011 - 2017 yılları için kurulan regresyon sonuçlarını göstermektedir. Endüstri 4.0 sonrası için az gelişmiş ülkelerde yeterli veri bulunmamasından dolayı regresyon sonuçları elde edilememiştir. Regresyon analizinde gelişmiş ülkeler $\mathrm{R}^{2}$ değerinin \%84, gelişmekte olan ülkeler $\mathrm{R}^{2}$ değerinin $\% 93$ oranında olduğu görülmektedir. Wald chi ${ }^{2}$ testi probility değerinin $\% 1$ seviyesinde anlamlı olduğu, regresyonları yorumlamanın istatistiki olarak uygun olduğu tespit edilmiştir. Elde edilen bulgularda ise büyüme (GDP) katsayılarının anlamlılık seviyesi gelişmiş (G1) ve gelişmekte olan (G2) ülkeler açısından \%10 düzeyinin dışında kalmıştır. 2011 sonrasındaki süreçte her iki ülke grubu açısından büyümenin istihdam üzerinde anlamlı bir etkisinin bulunmadığı söylenebilir. İşgücü (LFORCE) katsayıları ise \%1 seviyesinde anlamlılık göstermektedir. Bu durumda 2011 - 2017 yılları arasındaki süreçte işgücünde ortaya çıkan \%1'lik bir değişimde toplam istihdamı gelişmiş ülkelerde \%1.29 ve gelişmekte olan ülkelerde \%1.11 oranında arttırmaktadır.

Tablo 10'a göre Endüstri 4.0' dan sonraki süreçte teknoloji göstergeleri incelendiğinde gelişmiş ülkeler açısından Ar\&Ge harcamaları (RD) ve yüksek teknoloji ürün ihracatı (HTE) katsayılarının \%1 seviyesinde anlamlı bir etki içerdiğini, gelişmekte olan ülkeler açısından değerlendirildiğinde ise anlamlı bir etkinin bulunmadığı görülmektedir. Endüstri 4.0 sonrası verilerinde gelişmiş ülkelerde Ar\&Ge harcamalarındaki (RD) \%1 oranındaki artış sonucunda istihdamdaki azalış etkisinin \%0.56'dan \%1.01 oranına yükseldiği görülmektedir. Yüksek teknoloji ürün ihracatında (HTE) ise önceki süreçte anlamlı bir etkinin bulunmamasına rağmen sonraki süreçte anlamlı ve $\% 0.70$ seviyesinde pozitif bir etkinin olduğu görülmektedir. 
Gelişmiş ülkeler için Ar\&Ge harcamalarının (RD) istihdamı azaltıcı etkisi ile yüksek teknoloji ürün ihracatının istihdamı arttırıcı etkisi arasında \%0.31 oranında bir açık bulunduğu ve istihdam açısından yine de ciddi bir kayıp olduğu görülmektedir. Diğer taraftan ise anlamlı bir değişmenin bulunmuş olması gelişmiş ülkelerin Endüstri 4.0 için yaptıkları atılımların istihdam açısından olumlu etkilerinin olduğu söylenebilir. Süreç inovasyonu ile gerçekleşen istihdam daralmasının ürün üretimi sayesinde ortaya çıkan istihdam artışı ile kapatılabildiği fakat tam olarak istihdam azalışını karşılayamadığı görülmektedir. Gelişmekte olan ülkelerde ise anlamlı bir etkinin bulunmaması Dördüncü Sanayi Devriminin etkisinin belirsizliğinin bu ülke grupları için devam ettiği söylenebilir.

\section{SONUC}

İlk iki sanayi devrimi süreç olarak iki asırdan fazla sürse de Üçüncü Sanayi Devrimi bilişim teknolojilerinin gelişmesi ve bilginin daha hızlı yayılmasını sağlayarak daha kısa sürede yaygınlaşmıştır. Bütün bu süreçlerin ardından gelen Endüstri 4.0 aslında bugün farkedilemeyen çok büyük bir dönüşüm dalgasıdır. İlk üç sanayi devrimi tarım ve sanayi alanında büyük rol oynamış olsa da Dördüncü Sanayi Devriminin sadece tarım ve sanayi sektörlerini etkilemekle kalmayacağ 1 aynı zamanda hizmetler sektöründe de ciddi dönüşümlere neden olacağı yaşanan teknolojik gelişmeden anlaşılabilmektedir. Endüstri 4.0 ile ilgili istihdam teorileri genellikle insanların hukuk, tıp ve sanat gibi insanın mutlaka bulunacağı alanları etkilemeyeceğini öngörmektedir. Hergün yeni bir inovatif ürünün her alanda karşımıza çıkacak olması bu teoriyi çürütmektedir. Teknolojik ürünler sayesinde işgücünün yoğun olduğu ve insanın yerinin alınamayacağının düşünüldüğü alanlarda dahi yenilikler gerçekleşmektedir. Yapay zekâ haber spikerleri yaygınlaştığında birçok haber kanalı bu teknolojiyi kullanacaktır. Aynı zamanda yapay zekâ sağlık danışmanları, hukuk danışmanları, yapay zekâlı robot polisler ve yapay zekâ asistanlar yaygınlaşarak ciddi bir işsizlik artışına neden olacaktır. Ayrıca 3D yazıcılar ile araba, ev, basit el aletleri vb. şeylerin yapılmış olması üretim süreçlerinin daha bireysel ve esnek üretime neden olacağını göstermektedir. Özellikle uçak yapımı ve bina inşaatı gibi projelerde 3D yazıcıların kullanımı ile birlikte istihdam alanında ciddi sorunların ortaya çıkabileceğinin bir işaretidir. Ulaşım alanında ise sürücüsüz toplu taşıma araçları, sürücüsüz uçan arabalar gündeme gelmektedir. Dördüncü Sanayi Devrimi için birkaç örnek verilmiş olmasına rağmen ortaya çıkacak olan iş gücü fazlasının oldukça büyük olduğu tahmin edilebilir. Üstelik bu süreç çok uzak bir gelecekte yaşanmayacak 5-10 yıl gibi kısa bir süre içinde gerçekleşebilecektir. Diğger taraftan Nesnelerin İnterneti, Büyük Veri, Bulut Bilişim, Otonom Robotlar, Akıllı Fabrikalar, Arttırılmış Gerçeklik gibi diğer hayatı kolaylaştırıcı özelliklerin etkileri daha korkutucu düzeydedir. Akıllı Fabrikalar' in amacı iş gücünü sıfıra indirerek tamamen robotlarla yönetilen karanlık fabrikaların oluşmasını sağlamaktır. Bu fabrikalarda çalışacak olan iş gücü tamamen teknik donanıma sahip kişiler olacaktır. Diğer taraftan Arttırılmış Gerçeklik eğitim alanında öğretim sürecini daha eğlenceli ve görsel hale getirerek eğitimciyi bir danışman statüsüne geçirmektedir. Elbette yeni teknolojiler, yeni iş alanlarının açılmasına sebep olacak ve Endüstri 4.0' da olumlu etkilerin gelişmesine neden olabilecektir. Burada önem kazanan diğer bir konu gelecek için tasavvur edilemeyen, açılacak iş alanlarının kaybedilen iş alanlarının tazminini sağlaması hususudur. İstihdamı etkilemeyeceğini ifade eden teoriler kaybedilecek iş alanların yeni iş alanlarıyla tazmin edileceğini belirtmektedir. Lakin tazmin edilecek özellikle hizmet 
sektöründeki istihdam hacminin büyük olması nedeniyle kaybedilen iş alanlarının ne kadarını tazmin edebileceği açık bir şekilde belirlenememektedir.

Vivarelli (2013) çalışmasında yeni ürün üretimi ile istihdamın arttırıldığını, üretim sürecindeki teknolojik gelişmenin ise istihdamı azalttığını ifade etmektedir. Regresyon sonuçlarında Vivarelli'nin bu ifadesini destekleyici bulgular elde edilmiştir. Regresyon analizi sonuçlarında Ar\&Ge harcamaları (RD) ile istihdam arasındaki ilişkinin negatif olduğu, yani üretim süreçlerinde ortaya çıkan gelişmelerin istihdamı azalttığı görülmektedir. Yeni ürün üretimini temsil eden yüksek teknoloji ürün ihracatı (HTE) ile istihdam arasındaki ilişkinin pozitif olduğu görülmektedir. Regresyon sonuçları Vivarelli'nin tespitini doğrular niteliktedir. Ayrıca Ar\&Ge harcamalarının (RD) istihdamı azaltıcı etkilerinin göstergesi olan yüksek oranlı katsayılar ile yüksek teknoloji ürünleri ihracatının arttırıcı etki sağlayan düşük oranlı katsayılar arasındaki farkların, teknolojinin istihdamı azaltan etkilerinin istihdamı arttırıcı etkilerinden daha yüksek seviyelerde olduğu, bu durumda da yüksek işsizlik oranlarının ortaya çıkabileceği görülmektedir. Aradaki farkın istihdam arttırıcı politikalar tarafından dağıtılamadığı durumda yüksek işsizlik oranlarıyla karşılaşılabileceği tespit edilmiştir. "Teknolojik işsizlik" radikal teknolojik değişikliklerin yaşandığı dönemlerde ortaya çıkmaktadır (Vivarelli, 2013: 66). Teknolojik işsizlik ile karşılaşılması yüksek bir ihtimal içermektedir. Bu sebepten hükümetlerin bu konuda ortaya çıkacak iş gücü fazlasını tolere edecek istihdam politikaları geliştirmesi oldukça önemlidir.

Hükümetler Endüstri 4.0 başlangıcından itibaren yalnızca inovatif çalışmalara yönelmiştir. Ortaya çıkacak yüksek işsizlik ihtimali birçok iyimser fütürist tarafından göz ardı edilmektedir. $\mathrm{Bu}$ çalışmada ortaya çıkabilecek olan istihdam daralmalarının küçümsenmeyecek kadar yüksek oranlı olacağı regresyon sonuçları ile anlaşılmıştır. Bugüne kadar yaşanmış olan teknolojik dönüşümler sebebiyle ortaya çıkan işgücü fazlası uygulanan politikalar ve hizmetler sektöründe mevcut olan iş gücü talebi ile karşılanmıştır. Fakat Dördüncü Sanayi Devrimi hizmetler sektöründe ciddi bir işgücü fazlasının ortaya çıkmasına sebep olacak seviyededir. Hükümetler gündeme gelecek olan büyük ölçekli teknolojik işsizliği karşılaya bilecek bir politikaya sahip değillerdir. Bu sebepten öncelikle bu konuda çalışacak komisyonlar oluşturulmalı ve teknolojiyi geliştirirken aynı zamanda iş gücü talebi oluşturacak alanlar açılması sağlanmalıdır. Endüstri 4.0 süreci nedeniyle ortaya çıkabilecek olan istihdam sorununun önlenebilmesi için uygun politikaların üretilmesi ve yeni yatırım politikaları oluşturulması Türkiye açısından zorunludur.

\section{KAYNAKÇA}

Acemoğlu, D., \& Robinson, J. A. (2013). Ulusların Düşüşü: Güç, Zenginlik ve Yoksulluğun Kökenleri. Doğan Kitap, 8. Bask1, İstanbul, 2015.

Asteriou, D. \& Hall, SG 2007. Applied Econometrics-A Modern Approach using EViews and Microfit. Revised Edition.

Baltagi, B. (2008). Econometric Analysis of Panel Data. John Wiley \& Sons.

Bogliacino, F. (2014). Innovation And Employment: A Firm Level Analysis With European R\&D Scoreboard Data. EconomiA, 15(2), 141-154.

Bogliacino, F., Piva, M., \& Vivarelli, M. (2012). R\&D and Employment: An application of the LSDVC Estimator Using European Microdata. Economics Letters, 116(1), 56-59. 
Crespi, G., \& Zuniga, P. (2012). Innovation and Productivity: Evidence From Six Latin American Countries. World development, 40(2), 273-290.

Dachs, B., \& Peters, B. (2014). Innovation, Employment Growth, and Foreign Ownership Of Firms: A European Perspective. Research Policy, 43(1), 214-232.

Dam, M.M. (2016). Teknolojinin İşsizlik Üzerine Etkisi: OECD Ülkeleri İçin Panel Veri Analizi. Aydın İktisat Fakültesi, Eurefe (syf. 985-1002).

Derya, H. (2015). Alman Tarihçi Okulu; Klasik Okula Tepkileri. Gazi Kitapevi, Ankara.

Ebersberger, B. (2004). Labor Demand Effect of Public R\&D Funding. 2004, VIT Working Papers 9.

Feldmann, H. (2013). Technological Unemployment in Industrial Countries. Journal of Evolutionary Economics, 23(5), 1099-1126.

Güriş, S. (Ed.), (2018). Uygulamalı Panel Veri Ekonometrisi. Der Yayınları. 1. Baskı İstanbul.

Güriş, S., \& Kızılarslan, Ş. (2017). Dengesiz Panel Veri Modeli ile Em Algoritması Sonuçlarının Karşılaştırılması. Öneri Dergisi, 12(47), 15-30.

Harrison, R., Jaumandreu, J., Mairesse, J., \& Peters, B. (2014). Does Innovation Stimulate Employment? A Firm-Level Analysis Using Comparable Micro-Data From Four European Countries. International Journal of Industrial Organization, 35, 29-43.

Hausman, J. A. (1978). Specification Tests in Econometrics. Econometrica: Journal of the Econometric Society, 1251-1271.

Kara, M., \& Duruel, M. (2010). Türkiye'de Ekonomik Büyümenin İstihdam Yaratamama Sorunu. Sosyal Siyaset Konferansları Dergisi, (50), 367-396.

Karabulut, K., Özdemir, D., \& Shahinpour, A. (2019). Seçilmiş Ülkelerde Bilişim ve İletişim Teknolojilerinin (BIT) İşsizlik Üzerindeki Etkisi: Panel Veri Analizi. Ataturk University Journal of Economics \& Administrative Sciences, 33(4).

Kaynak, M. (2015). Büyüme Teorileri Giriş. Gazi Kitabevi, 3. Baskı. ISBN 978-605-344-220-2, Ankara.

Kendrick, J.W. (1956). Productivity Trends: Capital and Labor. National Bureau of Economic Research (NBER), Occasional Paper No: 53, New York.

Krousie, C. (2018). Technological Unemployment in the United States: A State-Level Analysis. Major Themes in Economics, 20(1), 87-101.

Kutlar A. (2017). Adım Adım EViews ile Panel Veri Ekonometrisi Uygulamaları. Umuttepe yayınları, 1. Baskı, Kocaeli.

Küçükalay, A.M. 2015. İktisadi Düşünce Tarihi. Beta Yayıncılık, İstanbul, 4. Baskı.

Lachenmaier, S., \& Rottmann, H. (2011). Effects of İnnovation on Employment: A Dynamic Panel Analysis. International Journal of Industrial Organization, 29(2), 210-220.

Özer, M., \& Çiftçi, N. (2009a). Ar-Ge Harcamaları ve İhracat İlişkisi: Oecd Ülkeleri Panel Veri Analizi. Dumlupınar Üniversitesi Sosyal Bilimler Dergisi, 23, 39-49. 
Piva, M., \& Vivarelli, M. (2018). Technological Change and Employment: Is Europe Ready For The Challenge?. Eurasian Business Review, 8(1), 13-32.

Solow, Robert M. (1956). "A Contribution to the Theory of Economic Growth", The Quarterly Journal of Economics, Vol.70, No.1, Feb., pp.65-94.

Tatoğlu F. Y. (2018). Panel Veri Ekonometrisi Stata Uygulamalı. Beta Yayınları, 4. Baskı, İstanbul.

Tatoğlu, F. Y. (2013). İleri Panel Veri Analizi Stata Uygulamalı. Beta Yayınları, 2. Baskı, İstanbul.

Van Roy, V., Vértesy, D., \& Vivarelli, M. (2018). Technology and Employment: Mass Unemployment or Job Creation? Empirical Evidence From European Patenting Firms. Research Policy, 47(9), 1762-1776.

Vivarelli, M. (2013). Technology, Employment and Skills: An İnterpretative Framework. Eurasian Business Review, 3(1), 66-89.

Vivarelli, M. (2015). Innovation and Employment. IZA World of Labor.

Wooldridge, J. M. (2015). Introductory Econometrics: A Modern Approach. Nelson Education. 